\title{
Interaction of Brine Concentration, Brine Temperature, and Presalting on Salt Penetration in Ragusano Cheese ${ }^{1}$
}

\author{
C. Melilli, ${ }^{\star}$ D. M. Barbano, $\dagger^{2}$ M. Caccamo, ${ }^{\star}$ L. Tuminello, ${ }^{\star}$ S. Carpino, ${ }^{\star}$ and G. Licitra*$¥$ \\ ${ }^{*}$ CoRFiLaC, Regione Siciliana, 97100 Ragusa, Italy \\ †Northeast Dairy Food Research Center, Department of Food Science, Cornell University, Ithaca, NY 14853 \\ $\ddagger$ Dipartimento di Scienze Agronomiche, Agrochimiche e delle Produzioni Animali, Catania University, 95100 Catania, Italy
}

\section{ABSTRACT}

Thirty-one $3.6-\mathrm{kg}$ blocks of Ragusano cheese were made on each of 6 different days (in different weeks) starting with a different batch of milk on each day. On $\mathrm{d} 1,3$, and 5 , the cheeses were not presalted and on $\mathrm{d}$ 2,4 , and 6 , all cheeses were presalted (PS). One of the 31 blocks of cheese was selected at random for analysis before brine salting (i.e., on d 0 ). The remaining 30 blocks were randomly divided into 2 groups of 15 blocks each; one group was placed in $18 \%$ brine $(18 \% \mathrm{~B})$ and the other group was placed in saturated brine (SB). For the 15 blocks within each of the 2 brine concentrations (BC), 5 blocks were placed in a brine tank at $12^{\circ} \mathrm{C}, 5$ at $15^{\circ} \mathrm{C}$, and 5 at $18^{\circ} \mathrm{C}$, and submerged for $24 \mathrm{~d}$. The research objective was to determine the combined impacts (i.e., interactions) of PS the curd before stretching, $\mathrm{BC}$ (SB vs. $18 \% \mathrm{~B}$ ), and brine temperature (BT; 12,15 , and $18^{\circ} \mathrm{C}$ ) on salt uptake, moisture content, and yield of Ragusano cheese. Although BC, BT, and PS each had their own separate impacts on salt uptake, there was little interaction of these effects on salt uptake when they were used in combination. The PS most quickly delivered salt to the interior of the cheese and was the most effective approach to salting for controlling early gas formation. There were strong separate impacts of $\mathrm{BC}, \mathrm{BT}$, and PS on cheese moisture content, moisture loss, and net weight loss, with BC having the largest separate impact on these parameters. Reducing BT reduced salt content and increased moisture, but the effects were small. The more important effect of reduced BT was to reduce growth of gas forming bacteria. The 18\%B produced higher moisture, and less moisture and weight loss than SB. The effect of interactions of BC,

\footnotetext{
Received July 18, 2005.

Accepted October 12, 2005.

${ }^{1}$ Use of names, names of ingredients, and identification of specific models of equipment is for scientific clarity and does not constitute any endorsement of product by authors, Cornell University, the Northeast Dairy Foods Research Center, CoRFiLaC, and Dipartimento di Scienze Agronomiche, Agrochimiche e delle Produzioni Animali, Catania University.

${ }^{2}$ Corresponding author: dmb37@cornell.edu
}

BT, and PS on moisture loss and net weight loss were small. To achieve the maximum benefit from the various approaches to salting for controlling early gas formation in Ragusano cheese, PS combined with slightly lower BT (i.e., $15^{\circ} \mathrm{C}$ instead of $18^{\circ} \mathrm{C}$ ) should be used. Although using 18\% B instead of SB did increase salt uptake, the point at which improved salt uptake occurred due to use of $18 \% \mathrm{~B}$ did not provide benefit in prevention of early gas formation, as reported separately. However, use of $18 \% \mathrm{~B}$ instead of SB provided a $9.98 \%$ increase in cheese yield due to reduced moisture loss during brining; this would be very attractive to cheese makers. The increase in yield needs to be balanced against the risk of growth of undesirable bacteria in the $18 \% \mathrm{~B}$ and the creation of another cheese quality defect.

Key words: brine, salt penetration, cheese yield

\section{INTRODUCTION}

Ragusano cheese is a brine-salted, pasta-filata raw milk cheese that is aged for 6 to 9 mo and is produced on farms in Eastern Sicily. Lactic acid is produced by natural milk microflora and desirable microflora from the surface of traditional wooden cheese vats (Licitra et al., 1998). The first 3 to $8 \mathrm{~d}$ of brine salting of Ragusano cheese is done on the farms and is followed by brine salting at an aging center. Typically, saturated brines $\left(18^{\circ} \mathrm{C}\right)$ are used at both locations. When salt uptake by cheese during brining is too slow, early gas formation and off-flavor development occur due to the growth of undesirable bacteria. The level of undesirable bacteria is dependent on their initial level in the milk (Choisy et al., 1987). Their growth is favored by slow acid production during cheese making (Choisy et al., 1987), slow salt penetration, and high temperature during brining. Resmini et al. (1974) found that salt uptake in Parmigiano-Reggiano cheese was faster when nonsaturated brine (approximately 16\%) was used for the first 5 to 6 $\mathrm{d}$ of brining followed by saturated brine (SB) until 24 d. A study on Ragusano cheese (Melilli et al., 2003a) demonstrated that use of $18 \%$ brine $(\mathbf{1 8 \%} \mathbf{B})$ instead of SB (i.e., about $26 \% \mathrm{wt} / \mathrm{wt}$ ) for the first $8 \mathrm{~d}$ of $24 \mathrm{~d}$ of brine 
salting increased the rate of salt uptake, compared with $24 \mathrm{~d}$ in SB, in agreement with the results of Resmini et al. (1974) for a non pasta-filata cheese. The cheese in $18 \% \mathrm{~B}$ at $18^{\circ} \mathrm{C}$ achieved the same salt content in 12 $\mathrm{d}$ as cheese in $\mathrm{SB}$ for $24 \mathrm{~d}$ at $18^{\circ} \mathrm{C}$. The increased rate of salt uptake with $18 \% \mathrm{~B}$ compared with SB was related to the impact of lower brine concentration (BC) on the moisture content and porosity of the cheese near the surface of the block (Melilli et al., 2003a). Brine with higher salt content causes a rapid loss of moisture from cheese near the surface of the block. Moisture loss causes shrinkage of the cheese structure and decreases porosity, which impedes moisture movement out and salt movement into the block (Melilli et al., 2003a, 2005). The use of $18 \%$ salt brine for the first $8 \mathrm{~d}$ delayed the moisture loss and cheese shrinkage at the exterior of the block and allowed more rapid salt penetration (Melilli et al., 2003a). Melilli et al. (2005) calculated the decrease in porosity at the exterior $1-\mathrm{mm}$ portion of the block that was 50.8 and $29.2 \%$ for cheeses that had been in SB vs. $18 \%$ B at 12 d, respectively. Even though the reduction in weight loss when using an $18 \% \mathrm{~B}$ makes a positive impact on cheese yield and the rate of salt penetration into the block, Melilli et al. (2004b) demonstrated that reducing BC did not have any impact on coliform count and had minimal impact on reducing early gas production in Ragusano cheese. A second approach to more quickly increase salt in the interior of Ragusano cheese was by presalting the curd before stretching. Melilli et al. (2003a) showed that cheese presalted (PS) before brining contained $60 \%$ of the salt content in the center of the block at $d 1$ compared with the salt content normally achieved after 24 $\mathrm{d}$ of brining with no presalting (NPS). Presalting did not change the rate of salt uptake from $18 \% \mathrm{~B}$ or $\mathrm{SB}$ (Melilli et al., 2003a) or moisture loss, but presalting the curd with $2 \%$ added salt before stretching reduced the coliform count in the cheese by $1.41 \mathrm{log}$ and made a major reduction in early gas formation (Melilli et al., 2004 b). Although presalting delivers about 2.5 to $3 \%$ salt in the water phase immediately to the center of the blocks of cheese (Melilli et al., 2003a), the large reduction in early gas formation in Ragusano cheese due to PS reported by Melilli et al. (2004b) was caused by the interaction of the temperature (about $48^{\circ} \mathrm{C}$ ), the low $\mathrm{pH}$ (about 5.2 to 5.3), and the PS during stretching and the ability of these conditions to kill gas-forming bacteria.

Brine temperature (BT) influences salt uptake during brining. Geurts et al. (1974) showed for Gouda cheese that salt diffusion at $20^{\circ} \mathrm{C}$ was higher by about 40 to $50 \%$ than at $12.5^{\circ} \mathrm{C}$. Turhan and Kaletunç (1992) found that for White cheese, a semihard pickled cheese (Carić, 1993), the salt penetration was slower with de- creasing BT because of decreased salt diffusivity. Melilli et al. (2003b) determined that salt uptake in Ragusano cheese increased with increasing BT from 12 to $24^{\circ} \mathrm{C}$, but at brine temperatures higher than $18^{\circ} \mathrm{C}$ a stimulation of early gas production was noted, even though the salt uptake by the cheese was faster. Reducing brine temperature from 18 to $12^{\circ} \mathrm{C}$ made a larger reduction in early gas formation in cheeses that were not presalted (from 6.8 to $1.8 \%$ gas holes, respectively) than in cheeses that were presalted (from 1.9 to $0.5 \%$ gas holes, respectively; Melilli et al., 2004b).

Brine-salted cheeses generally lose weight during brining, even though they are taking up salt. Geurts et al. $(1974,1980)$ reported that the net weight loss from cheese during brining is due to moisture loss. Melilli et al. (2003a) reported an $11.3 \%$ weight loss from $3.5 \mathrm{~kg}$ blocks of brine salted Ragusano cheese and the shrinkage of block size was estimated to be $10.4 \%$. This was consistent with a report of $14 \%$ shrinkage for Gouda cheese reported by Payne and Morison (1999). Shrinkage does not occur uniformly within the block and Geurts et al. (1980) estimated that the exterior portion of a block might shrink by as much as $30 \%$. Shrinkage of the exterior portion of the block changes the microstructure near the block surface forming a barrier layer very early (i.e., first 24 to $48 \mathrm{~h}$ ) in the brining process (Melilli et al., 2005). However, surface shrinkage does contribute to the typical shape of the Ragusano blocks of cheese by converting the flat-sided rectangular block with $90^{\circ}$ angles on the edges into a block that has rounded edges and corners. The rounding of the block shape at the edges is caused by the faster rate of moisture loss at the edges and corners of the block compared with the moisture loss from the flat center faces of the rectangular block. The surface barrier layer influences salt uptake during the remainder of the brining process. Weight loss during brining reduces cheese yield; therefore, it would be desirable to optimize cheese-making and brining conditions to provide maximum reduction in early gas formation while maintaining the highest possible cheese yield. The objective of this research was to determine the combined impact (i.e., interactions) of PS the curd before stretching, BC (saturated vs. 18\% salt brine), and $\mathrm{BT}\left(12,15\right.$, and $\left.18^{\circ} \mathrm{C}\right)$ on salt uptake, moisture content, and yield of Ragusano cheese.

\section{MATERIALS AND METHODS}

\section{Experimental Design and Statistical Analyses}

Thirty-one 3.6-kg blocks of Ragusano cheese were made on each of 6 different days (in different weeks) starting with a different batch of milk on each day. On $\mathrm{d} 1,3$, and 5 , the cheeses were not presalted and on $\mathrm{d}$ 2,4 , and 6 all cheeses were presalted. One of the 31 
blocks of cheese was selected at random for analysis before brine salting (i.e., $\mathrm{d} 0$ ). The remaining 30 blocks were randomly divided into 2 groups of 15 blocks each; one group was placed in $18 \% \mathrm{~B}$ and the other group was placed in SB. For the 15 blocks within each of the 2 BC, 5 blocks were placed in a brine tank at $12^{\circ} \mathrm{C}, 5$ at $15^{\circ} \mathrm{C}$, and 5 at $18^{\circ} \mathrm{C}$. Cheese blocks were sampled immediately before brine salting (d 0) and after 1, 4, 8, 16 , and $24 \mathrm{~d}$ of brine salting.

Data were analyzed using the GLM procedure of SAS (version 8, 1999; SAS Institute, Inc., Cary, NC). Weight of the blocks of cheese, $\mathrm{pH}$, moisture, salt, and salt in moisture content were determined at $0,1,4,8,16$, and $24 \mathrm{~d}$ of brining. Because time of brining was treated as a continuous variable in the ANOVA model, the linear and quadratic terms for time would be correlated. Distortion of the ANOVA by multicollinearity of these terms in the model was minimized by centering the time of brining data using a mathematical transformation (Glantz and Slinker, 2001). The time was transformed as follows: time $=\mathrm{d}$ of brining $-[$ (last testing day - first testing day)/2]. This transformation made the data set orthogonal with respect to time.

\section{Cheese Making}

Six cheese makings were done from February to March 2003. Milk produced by Brown Swiss, Holstein, and mixed-breed cows from 3 farms, from both milkings (morning and evening) was commingled and transported to the CoRFiLaC pilot plant (eastern Sicily). The raw whole milk $(1,300 \mathrm{~L})$ was heated in a plate-andframe heat exchanger to $35^{\circ} \mathrm{C}$ and pumped directly into 7 traditional wooden cheese vats and Ragusano cheese was manufactured using the procedures described by Melilli et al. (2003a,b). The milled curd was weighed and divided into 31 batches of $4 \mathrm{~kg}$ of curd each. Three cheese makers stretched 31 batches of curd to produce 31 blocks of cheese $(15.2 \times 15.2 \times 15.2 \mathrm{~cm})$ that weighed approximately $3.6 \mathrm{~kg}$ after stretching. On 3 different days of cheese making, the cheese makers stretched 31 NPS cheeses and, during another 3 days, the cheese makers stretched 31 PS cheeses, following the procedures of Melilli et al. (2003a,b). On cheese-making d 2, 4 , and 6 , the curd to make all 31 blocks of cheese was presalted at a rate of $2 \%$ added salt and each block was stretched in $10 \mathrm{~L}$ of hot brine $(4.5 \%$ salt, $\mathrm{wt} / \mathrm{vol})$ to minimize salt loss during stretching (Melilli et al., 2003a). The average temperature and $\mathrm{pH}$ of the curd during stretching were about $48^{\circ} \mathrm{C}$ and 5.30 , respectively.

Each 3.6-kg block of cheese was marked with a letter (treatment) and a number (sampling day) so that the cheese could be correctly identified in the brine tank.
After forming the blocks, 1 of the 31 blocks was sampled and analyzed before brining. The initial SB used in this experiment was one that had been used for many years in a commercial Ragusano cheese-aging center. Old SB was used because it contained a normal calcium and lactate content, and had a $\mathrm{pH}$ of about 5.2 , which would avoid the defect of cheese-rind softening, the loss of the deep yellow color, and stickiness (Geurts et al., 1972) that can occur with a new brine that contains no calcium and has high $\mathrm{pH}$. The $18 \% \mathrm{~B}$ solution was prepared from some of the SB by diluting with water to reach a concentration of $18 \%$ salt (wt/vol). The $\mathrm{pH}$ of the $18 \%$ brine was adjusted by directly adding lactic acid to achieve the same $\mathrm{pH}$ (approximately 5.20) as the saturated brine. The brines were prepared $15 \mathrm{~d}$ before the experiment and placed in tanks in controlled temperature rooms to equilibrate before the beginning of the experiment. Furthermore, during this 15 -d period before initiation of the study, blocks of regular Ragusano cheese were placed into each brine to equilibrate the calcium content. The ratio of the volume of brine to volume of experimental blocks of cheese was kept at 5 or greater (Zorrilla and Rubiolo, 1991) so that the ratio of the volume of brine to cheese would not limit salt uptake during the experiment. The blocks were kept submerged for $24 \mathrm{~d}$. During the $24 \mathrm{~d}$ of brining the blocks of cheese were turned daily and the salinity of the brine was checked 4 times/d with a hydrometer and adjusted to maintain either saturation or $18 \%$ salt concentration during each day as needed.

\section{Milk for Cheese Making}

Milk samples were collected, randomly, from 1 of the 7 vats, at $35^{\circ} \mathrm{C}$, and they were tested for fat, crude protein, and lactose content using an infrared milk analyzer (AOAC, 2000; method number 33.2.31; 972.16), for SCC using a Fossomatic cell counter (AOAC, 2000; method number $17.13 .01 ; 978.26$ ), for the titratable acidity, and $\mathrm{pH}$. The average raw whole milk used in 3 cheese-making sessions had an acidity of $0.13 \mathrm{~g}$ lactic acid/100 $\mathrm{mL}$ and a $\mathrm{pH}$ of 6.70 at $35^{\circ} \mathrm{C}$. The average fat, $\mathrm{CP}$, and lactose content were $3.26,3.27$, and $4.70 \%$ respectively, with an average SCC of 400,000 cells/mL.

\section{Sampling and Analysis of Cheese}

Each experimental block $(15.2 \times 15.2 \times 15.2 \mathrm{~cm})$ of Ragusano cheese, on each sampling day, was weighed and divided in 4 portions (P1, P2, P3, and P4) using a meat slicer (model 601003, Electrolux, Zanussi Italia s.p.a, Pordenone, Italy), as described by Melilli et al. (2003a,b). The exterior portion (P1) represented all 6 faces of the block (approximately 0.6-cm thick); after removal of the $\mathrm{P} 1$ portion, the $\mathrm{P} 2$ portion was removed 
(approximately 1-cm thick) from all 6 faces of the block. The P3 portion (approximately 1-cm thick) was removed next, leaving a cube of about $10 \times 10 \times 10 \mathrm{~cm}$ as the central portion (P4) of the cheese block. Cheeses were sampled at 0 time (before brining), 1, 4, 8, 16, and 24 $\mathrm{d}$ of brining. Each portion (P1, P2, P3, and P4) was weighed, cut into cubes, and grated. Moisture content was determined by drying a 3-g sample in a forced air oven at $100^{\circ} \mathrm{C}$ for $24 \mathrm{~h}$ (AOAC, 2000 , method number $33.2 .44 ; 990.20)$, salt content by the Volhard method (AOAC, 2000, method number 33.7.1; 935.43), and the $\mathrm{pH}$ with a gel-filled electrode (model: HA405-DXK-S8/ 120, Mettler Toledo Process Analytical Inc., Wilmington, MA).

\section{RESULTS}

\section{Total Weight and Moisture Loss, and Total Moisture and Salt Uptake During Brining}

All of the 3.6-kg blocks lost between 190 to $500 \mathrm{~g}$ in $24 \mathrm{~d}$ of brining (Table 1). The weight of each block of cheese is presented in Table 1 and the salt content of each block of cheese will be presented later in the paper. Using these weights, researchers that are in interested in mathematical modeling of factors influencing salt movement in cheese will have access to the data. There was an impact $(P<0.01)$ of $\mathrm{BC}$ on mean total weight loss during brining (Table 2). Cheeses kept in saturated brine for $24 \mathrm{~d}$ lost more $(P<0.01)$ weight than the cheeses in $18 \% \mathrm{~B}$ (Table 2, Figure 1). There was a significant linear $(t)$ and quadratic $(t \times t)$ effect of time on total weight loss, and a significant interaction of time (linear and quadratic) with BC (Table 2, Figure 1) with a slower rate of weight loss for the $18 \% \mathrm{~B}$ than the SB cheeses with time of brining. Cheeses kept in a SB for $24 \mathrm{~d}$ had higher least square mean total weight loss than cheeses kept at 18\% B (Table 3 ). The second largest impact on total weight loss was due to BT (Table 2). The cheeses that were kept at higher BT $\left(18^{\circ} \mathrm{C}\right)$ for 24 $\mathrm{d}$ lost more $(P<0.01)$ weight than the cheeses at lower BT (Table 2, Figure 2). The cheeses kept at $18^{\circ} \mathrm{C}$ for $24 \mathrm{~d}$ had higher least squares mean weight loss than cheeses kept at $12^{\circ} \mathrm{C}(197$ vs. $167 \mathrm{~g}$; Table 3) and a faster rate of weight loss over time $(\mathrm{t} \times \mathrm{BT}$ interaction; Table 2, Figure 2). Even though there was no direct effect of PS on weight loss, there was an interaction $(P=0.03)$ of PS $\times$ BC. The cheese that was PS and held in $18 \% \mathrm{~B}$ lost less total weight, whereas PS cheeses in SB lost slightly more total weight (Table 3 ). There was no interaction $(P>0.05)$ of $\mathrm{BC}$ and $\mathrm{BT}$ or 3 -way interaction of BC, BT, and PS on total weight loss (Table 2).

Salt present in the blocks due to PS was not counted as part of salt uptake from brine, but is considered later in the salt content of the cheese. Total salt uptake from brine was influenced $(P<0.01)$ by $\mathrm{BC}$, but not directly by BT and PS (Table 2). The least squares mean total salt uptake (Table 3 ) was higher for $18 \% \mathrm{~B}$ cheeses than for the SB cheeses, and there was an interaction $(P=$ 0.01) of BC with time (linear and quadratic) of brining (Table 2, Figure 3). The overall least squares mean uptake of salt from brine was not influenced by presalting the cheese before brining (Table 3), but there was a BC $\times$ PS interaction (Table $2 ; P=0.01$ ). The PS cheeses in SB took up slightly more salt, whereas the PS cheeses in $18 \% \mathrm{~B}$ took up slightly less salt (Table 3 ), than the corresponding NPS cheeses.

There was an effect of BC $(P<0.01)$ on loss of total moisture (Table 2). Least squares mean moisture loss was higher for cheeses in SB (Table 3). Loss of moisture increased with time of brining (Figure 4), and there was an interaction of $\mathrm{BC}$ with time (linear and quadratic terms) of brining (Table 2, Figure 4). There was a difference in moisture loss even after $1 \mathrm{~d}$ of brining and the difference got progressively larger with increasing time of brining (Figure 4). More than $50 \%$ of the moisture loss occurred during the first $8 \mathrm{~d}$ of brining, as reported in previous studies (Melilli et al., 2003a,b). There was no impact detected $(P>0.05)$ of BT and PS on total moisture loss (Table 2).

\section{Salt and Moisture Concentration in the Cheese During Brining}

Percentage salt in the cheese was primarily influenced $(P<0.01)$ by PS (Tables 2 and 4, Figure 5). Presalting produced a higher salt content both initially and throughout $24 \mathrm{~d}$ of brining (Table 3, Figure 5). All cheeses increased in salt concentration with time of brining (Table 4). Brine concentration and its interaction with the quadratic term for time of brining was significant $(P=0.01)$, with cheeses left $24 \mathrm{~d}$ in $18 \% \mathrm{~B}$ having higher salt content than cheeses in SB (Tables 2 and 4, Figure 6). The interaction between BC and PS had an effect (Table 2; $P=0.01$ ) on salt concentration in the cheese. Without PS, the salt content of the cheese in $24 \mathrm{~d}$ was higher (i.e., 2.50 vs. $2.09 \%$ ) for cheese in $18 \% \mathrm{~B}$ (Table 3). When the cheese was PS there was very little influence (3.00 vs. $3.14 \%)$ on the least squares mean total salt concentration (Table 3). However, PS increased (71 vs. $67 \mathrm{~g}$; Table 3) the least squares mean total uptake of salt of the cheeses in SB $(B C \times$ PS interaction; Table 2) whereas it decreased (79 vs. 84 g; Table 3 ) the least squares mean total salt uptake in $18 \% \mathrm{~B}$. In spite of this small difference in salt uptake, the direct effect of PS on final percentage salt was large (Table 4), particularly in the P4 portion. Thus, PS had a larger impact on final salt percentage in SB cheeses than in $18 \% \mathrm{~B}$ cheeses. 
Table 1. Weight (g) in $24 \mathrm{~d}$ of brining time, for portions P1, P2, P3, and P4 of each treatment ${ }^{1}$

\begin{tabular}{|c|c|c|c|c|c|c|c|c|c|c|c|c|}
\hline \multirow[b]{2}{*}{ Day } & \multicolumn{6}{|c|}{ Presalted cheeses } & \multicolumn{6}{|c|}{ Nonpresalted cheeses } \\
\hline & P1 & P2 & P3 & $\mathrm{P} 4$ & $\begin{array}{l}\text { Total } \\
\text { weight }\end{array}$ & $\begin{array}{l}\text { Original } \\
\text { weight }\end{array}$ & $\mathrm{P} 1$ & $\mathrm{P} 2$ & P3 & $\mathrm{P} 4$ & $\begin{array}{l}\text { Total } \\
\text { weight }\end{array}$ & $\begin{array}{l}\text { Original } \\
\text { weight }\end{array}$ \\
\hline & \multicolumn{12}{|c|}{ Saturated brine at $12^{\circ} \mathrm{C}$} \\
\hline 0 & 748 & 1,117 & 791 & 1,066 & 3,722 & 3,727 & 695 & 955 & 792 & 1,123 & 3,565 & 3,571 \\
\hline 1 & 887 & 1,066 & 744 & 951 & 3,648 & 3,732 & 807 & 984 & 707 & 986 & 3,484 & 3,574 \\
\hline 4 & 945 & 1,029 & 683 & 846 & 3,503 & 3,687 & 928 & 971 & 657 & 851 & 3,407 & 3,592 \\
\hline 8 & 958 & 1,022 & 647 & 754 & 3,381 & 3,639 & 955 & 971 & 615 & 748 & 3,289 & 3,545 \\
\hline 16 & 977 & 1,071 & 652 & 669 & 3,370 & 3,729 & 878 & 980 & 609 & 690 & 3,157 & 3,498 \\
\hline 24 & 1,016 & 1,039 & 639 & 626 & 3,319 & 3,740 & 962 & 1,007 & 592 & 599 & 3,160 & 3,595 \\
\hline 0 & 748 & 1,117 & 791 & 1,066 & 3,722 & 3,727 & 695 & 955 & 792 & 1,123 & 3,565 & 3,571 \\
\hline 1 & 866 & 1,069 & 747 & 969 & 3,651 & 3,705 & 816 & 998 & 705 & 946 & 3,465 & 3,522 \\
\hline 4 & 935 & 1,077 & 705 & 859 & 3,576 & 3,689 & 915 & 1,016 & 665 & 838 & 3,435 & 3,552 \\
\hline 8 & 909 & 1,098 & 703 & 828 & 3,538 & 3,683 & 932 & 1,052 & 665 & 791 & 3,441 & 3,597 \\
\hline 16 & 941 & 1,105 & 713 & 767 & 3,525 & 3,719 & 869 & 1,055 & 668 & 748 & 3,340 & 3,530 \\
\hline 24 & 932 & 1,117 & 714 & 739 & 3,503 & 3,695 & 929 & 1,089 & 666 & 665 & 3,349 & 3,601 \\
\hline \multicolumn{13}{|c|}{ Saturated brine at $15^{\circ} \mathrm{C}$} \\
\hline 0 & 748 & 1,117 & 791 & 1,066 & 3,722 & 3,727 & 695 & 955 & 792 & 1,123 & 3,565 & 3,571 \\
\hline 1 & 868 & 1,049 & 745 & 985 & 3,648 & 3,745 & 801 & 987 & 717 & 995 & 3,500 & 3,595 \\
\hline 4 & 935 & 998 & 667 & 871 & 3,471 & 3,664 & 906 & 946 & 643 & 873 & 3,367 & 3,549 \\
\hline 8 & 963 & 1,025 & 641 & 779 & 3,407 & 3,696 & 938 & 951 & 614 & 791 & 3,295 & 3,563 \\
\hline 16 & 939 & 1,068 & 649 & 683 & 3,339 & 3,722 & 839 & 1,013 & 633 & 723 & 3,209 & 3,591 \\
\hline 24 & 972 & 1,051 & 637 & 606 & 3,266 & 3,714 & 926 & 989 & 580 & 585 & 3,079 & 3,531 \\
\hline \multicolumn{13}{|c|}{$18 \%$ Brine at $15^{\circ} \mathrm{C}$} \\
\hline 0 & 748 & 1,117 & 791 & 1,066 & 3,722 & 3,727 & 695 & 955 & 792 & 1,123 & 3,565 & 3,571 \\
\hline 1 & 859 & 1,061 & 752 & 977 & 3,649 & 3,710 & 823 & 987 & 712 & 989 & 3,511 & 3,572 \\
\hline 4 & 938 & 1,049 & 699 & 888 & 3,574 & 3,708 & 913 & 998 & 657 & 850 & 3,418 & 3,549 \\
\hline 8 & 954 & 1,074 & 700 & 809 & 3,537 & 3,690 & 921 & 1,013 & 636 & 769 & 3,339 & 3,507 \\
\hline 16 & 975 & 1,099 & 703 & 747 & 3,524 & 3,735 & 889 & 1,059 & 651 & 736 & 3,335 & 3,543 \\
\hline 24 & 943 & 1,134 & 714 & 723 & 3,514 & 3,757 & 897 & 1,070 & 649 & 647 & 3,263 & 3,547 \\
\hline \multicolumn{13}{|c|}{ Saturated brine at $18^{\circ} \mathrm{C}-$} \\
\hline 0 & 748 & 1,117 & 791 & 1,066 & 3,722 & 3,727 & 695 & 955 & 792 & 1,123 & 3,565 & 3,571 \\
\hline 1 & 855 & 1,025 & 731 & 969 & 3,580 & 3,677 & 779 & 958 & 705 & 1,013 & 3,455 & 3,550 \\
\hline 4 & 935 & 1,020 & 682 & 892 & 3,529 & 3,751 & 879 & 944 & 645 & 877 & 3,345 & 3,556 \\
\hline 8 & 927 & 1,034 & 647 & 774 & 3,382 & 3,690 & 907 & 952 & 611 & 801 & 3,270 & 3,545 \\
\hline 16 & 908 & 1,070 & 647 & 697 & 3,321 & 3,734 & 797 & 1,009 & 623 & 753 & 3,182 & 3,569 \\
\hline 24 & 897 & 1,114 & 612 & 613 & 3,236 & 3,700 & 839 & 1,001 & 587 & 630 & 3,058 & 3,561 \\
\hline \multicolumn{13}{|c|}{$18 \%$ Brine at $18^{\circ} \mathrm{C}$} \\
\hline 0 & 748 & 1,117 & 791 & 1,066 & 3,722 & 3,727 & 695 & 955 & 792 & 1,123 & 3,565 & 3,571 \\
\hline 1 & 851 & 1,061 & 751 & 975 & 3,638 & 3,708 & 797 & 971 & 699 & 983 & 3,450 & 3,522 \\
\hline 4 & 913 & 1,049 & 697 & 919 & 3,577 & 3,725 & 899 & 987 & 653 & 871 & 3,409 & 3,555 \\
\hline 8 & 917 & 1,100 & 695 & 843 & 3,555 & 3,744 & 910 & 1,010 & 636 & 797 & 3,353 & 3,539 \\
\hline 16 & 913 & 1,131 & 701 & 746 & 3,491 & 3,733 & 786 & 1,059 & 670 & 1,059 & 3,575 & 3,549 \\
\hline 24 & 833 & 1,140 & 724 & 764 & 3,461 & 3,725 & 843 & 1,076 & 663 & 682 & 3,263 & 3,591 \\
\hline
\end{tabular}

${ }^{1}$ Treatments: presalting the curd (presalted vs. not presalted), brine concentration (saturated brine vs. $18 \%$ brine), and brine temperature $\left(12,15\right.$, and $\left.18^{\circ} \mathrm{C}\right) . \mathrm{P} 1, \mathrm{P} 2, \mathrm{P} 3$, and $\mathrm{P} 4$ represent portions of the cheese block from exterior surface (P1) to interior core (P4).

Percentage moisture in the cheese was influenced the most $(P<0.01)$ by $\mathrm{BC}$ and by its interaction with time (linear and quadratic) of brining (Table 2, Figure 7). Percentage moisture was higher for $18 \% \mathrm{~B}$ cheeses than for SB cheeses (Figure 7) and this influenced cheese yield (i.e., smaller weight loss). The effect of BT was also significant $(P<0.01)$ and its interaction with the linear term for time of brining $(P=0.05)$. Cheeses left $24 \mathrm{~d}$ in brine at $18^{\circ} \mathrm{C}$ had a lower moisture percent than the cheeses left $24 \mathrm{~d}$ at lower brine temperatures
(Tables 2 and 3, Figure 8). Fat and protein content (data not shown) of the cheeses in this study changed in concentration on a wet basis in an inverse relationship with moisture content of the cheese.

\section{Moisture, Salt, and pH Variation Within Blocks During Brining}

Moisture. There was an impact of $\mathrm{BC}$ on moisture content of cheese in all portions within the block, but the 
Table 2. Sums of the squares (Type III SS) and probability values (in parentheses) for the ANOVA of the impact of treatments ${ }^{1}$ on the total weight loss, total moisture loss, salt uptake, and percentage salt and moisture of Ragusano cheese over $24 \mathrm{~d}$ of brining

\begin{tabular}{|c|c|c|c|c|c|c|}
\hline Factors $^{2}$ & df & $\begin{array}{l}\text { Total weight } \\
\text { loss }(\mathrm{g})\end{array}$ & $\begin{array}{l}\text { Total salt } \\
\text { uptake (g) }\end{array}$ & $\begin{array}{l}\text { Total } \\
\text { moisture } \\
\text { loss }(\mathrm{g})\end{array}$ & $\begin{array}{l}\text { Salt } \\
(\%)\end{array}$ & $\begin{array}{l}\text { Moisture } \\
(\%)\end{array}$ \\
\hline \multicolumn{7}{|l|}{ Whole plot } \\
\hline $\mathrm{BC}$ & 1 & $\begin{array}{r}316,102^{*} \\
(<0.01)\end{array}$ & $\begin{array}{l}8,102^{*} \\
\quad(<0.01)\end{array}$ & $\begin{array}{r}285,179^{*} \\
(<0.01)\end{array}$ & $\begin{array}{l}4.46^{*} \\
(0.01)\end{array}$ & $\begin{array}{l}89.00^{*} \\
(<0.01)\end{array}$ \\
\hline $\mathrm{BT}$ & 2 & $\begin{array}{r}39,234^{*} \\
(<0.01)\end{array}$ & $\begin{array}{l}67 \\
(0.67)\end{array}$ & $\begin{array}{r}10,342 \\
(0.07)\end{array}$ & $\begin{array}{c}0.11 \\
(0.50)\end{array}$ & $\begin{array}{l}18.87^{*} \\
(<0.01)\end{array}$ \\
\hline PS & 1 & $\begin{array}{l}91 \\
(0.57)\end{array}$ & $\begin{array}{l}14 \\
(0.69)\end{array}$ & $\begin{array}{l}175 \\
(0.72)\end{array}$ & $\begin{array}{l}32.71^{*} \\
(<0.01)\end{array}$ & $\begin{array}{l}1.71^{*} \\
(0.01)\end{array}$ \\
\hline $\mathrm{BC} \times \mathrm{PS}$ & 1 & $\begin{array}{l}2,091^{*} \\
\quad(0.03)\end{array}$ & $\begin{array}{l}959^{*} \\
(0.01)\end{array}$ & NS & $\begin{array}{l}1.10^{*} \\
(0.01)\end{array}$ & $\begin{array}{l}3.83^{*} \\
(0.01)\end{array}$ \\
\hline $\mathrm{BC} \times \mathrm{BT} \times \mathrm{PS}$ & 7 & $\begin{array}{l}1,489 \\
(0.94)\end{array}$ & $\begin{array}{l}467 \\
\quad(0.67)\end{array}$ & $\begin{array}{l}8,919 \\
\quad(0.41)\end{array}$ & $\begin{array}{c}0.44 \\
(0.69)\end{array}$ & $\begin{array}{c}0.48 \\
(1.00)\end{array}$ \\
\hline \multicolumn{7}{|l|}{ Subplot } \\
\hline $\mathrm{t}$ & 1 & $\begin{array}{r}2,568,107^{*} \\
(<0.01)\end{array}$ & $\begin{array}{r}415,512^{*} \\
(<0.01)\end{array}$ & $\begin{array}{r}5,049,611^{*} \\
(<0.01)\end{array}$ & $\begin{array}{l}399.20^{*} \\
(<0.01)\end{array}$ & $\begin{array}{r}1,971.65^{*} \\
(<0.01)\end{array}$ \\
\hline $\mathrm{t} \times \mathrm{BC}$ & 1 & $\begin{array}{r}215,100^{*} \\
(<0.01)\end{array}$ & $\begin{array}{l}1,772^{*} \\
(0.01)\end{array}$ & $\begin{array}{r}201,369^{*} \\
(<0.01)\end{array}$ & NS & $\begin{array}{r}75.02 * \\
(<0.01)\end{array}$ \\
\hline $\mathrm{t} \times \mathrm{BT}$ & 2 & $\begin{array}{r}9,418^{*} \\
(0.01)\end{array}$ & $\mathrm{NS}$ & $\mathrm{NS}$ & NS & $\begin{array}{r}5.80^{*} \\
(0.05)\end{array}$ \\
\hline $\mathrm{t} \times \mathrm{t}$ & 1 & $\begin{array}{r}251,740^{*} \\
(<0.01)\end{array}$ & $\begin{array}{l}40,854^{*} \\
\quad(<0.01)\end{array}$ & $\begin{array}{r}495,420^{*} \\
(<0.01)\end{array}$ & $\begin{array}{l}34.33^{*} \\
(<0.01)\end{array}$ & $\begin{array}{r}211.85^{*} \\
(<0.01)\end{array}$ \\
\hline$(\mathrm{t} \times \mathrm{t}) \times \mathrm{BC}$ & 1 & $\begin{array}{r}15,413^{*} \\
(<0.01)\end{array}$ & $\begin{array}{l}1,497^{*} \\
(0.01)\end{array}$ & $\begin{array}{r}12,612^{*} \\
(0.01)\end{array}$ & $\begin{array}{l}1.42^{*} \\
(0.01)\end{array}$ & $\begin{array}{l}5.10^{*} \\
(0.02)\end{array}$ \\
\hline Error & 198 & 165,184 & - & - & - & 189.19 \\
\hline Error & 200 & - & 23,221 & 246,862 & - & - \\
\hline Error & 201 & - & - & - & 22.51 & - \\
\hline $\mathrm{R}^{2}$ & & 0.96 & 0.95 & 0.96 & 0.96 & 0.93 \\
\hline
\end{tabular}

${ }^{1}$ Treatments: presalting the curd (presalted vs. not presalted), brine concentration (saturated brine vs. $18 \%$ brine), and brine temperature $\left(12,15\right.$, and $\left.18^{\circ} \mathrm{C}\right) . \mathrm{P} 1, \mathrm{P} 2, \mathrm{P} 3$, and $\mathrm{P} 4$ represent portions of the cheese block from exterior surface (P1) to interior core (P4).

${ }^{2}$ Factors: $\mathrm{BC}=$ brine concentration; $\mathrm{BT}=$ brine temperature; $\mathrm{PS}=$ presalting; $\mathrm{t}=$ time.

*Statistically significant $(P<0.05)$.

magnitude of the impact of $\mathrm{BC}$ on moisture decreased greatly from portions P1 to P4 (Table 5). Overall, the impact of $\mathrm{BC}$ produced the largest effect on moisture

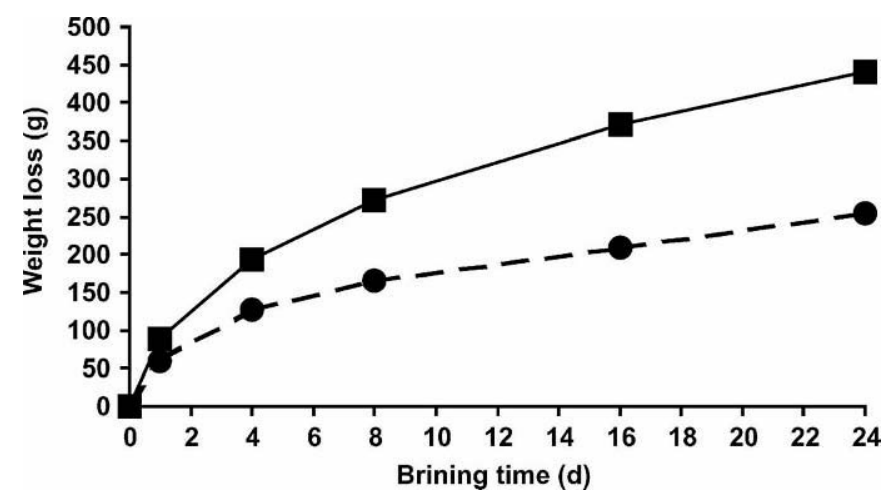

Figure 1. Impact of brine concentration, $18 \%$ brine $(0)$ vs. saturated brine ( $\mathbf{\square})$, on total weight loss (g) in Ragusano cheese at 0,1 , $4,8,16$, and $24 \mathrm{~d}$ of brining. content in $\mathrm{P} 1$, followed by BT, and then by PS. In portion $\mathrm{P} 1$, the $18 \% \mathrm{~B}$ cheeses had higher $(P<0.01)$ moisture than the SB cheeses (Figure 9, Table 6). There was also a significant $(P<0.01)$ interaction of $\mathrm{BC}$ with time (linear and quadratic) with the 24-d-old cheeses in $18 \% \mathrm{~B}$ having higher moisture content in the $\mathrm{P} 1$ portion (approximately 34\%) than the cheeses held in the SB (approximately 27\%; Figure 9). Final moisture content of the $\mathrm{P} 1$ portion reached in $24 \mathrm{~d}$ of brining in the cheese left in $18 \% \mathrm{~B}$ was nearly achieved in $4 \mathrm{~d}$ of brining, whereas the cheese in SB continued to lose a large amount of moisture after d 4 (Figure 9). Higher moisture content would be expected to maintain higher porosity of the exterior $(\mathrm{P} 1)$ portion of the cheese at $18 \% \mathrm{~B}$ and permit faster salt uptake. There was an effect $(P$ $<0.01$ ) of BT on moisture content in P1 (Table 5), with least squares mean moisture content higher for the cheeses kept $24 \mathrm{~d}$ at 12 and $15^{\circ} \mathrm{C}$ than those kept at $18^{\circ} \mathrm{C}$ (Figure 10, Table 6). There was a significant linear interaction of $\mathrm{BT}$ with time $(P=0.04$; Table 5 , Figure 
Table 3. Least squares mean values of the total weight loss, total moisture loss, and salt (uptake and percentage) and moisture percentage for presalted and not presalted cheeses at 2 brine concentrations (18\% vs. saturated), and 3 brining temperatures $\left(12,15\right.$, and $\left.18^{\circ} \mathrm{C}\right)$ over $24 \mathrm{~d}$ of brining

\begin{tabular}{|c|c|c|c|c|c|}
\hline Variable & $\begin{array}{l}\text { Total } \\
\text { weight } \\
\text { loss } \\
\text { (g) }\end{array}$ & $\begin{array}{l}\text { Total } \\
\text { salt } \\
\text { uptake } \\
\text { (g) }\end{array}$ & $\begin{array}{l}\text { Total } \\
\text { moisture } \\
\text { loss } \\
(\mathrm{g})\end{array}$ & $\begin{array}{l}\text { Salt } \\
(\%)\end{array}$ & $\begin{array}{l}\text { Moisture } \\
(\%)\end{array}$ \\
\hline Presalting & $181^{\mathrm{a}}$ & $75^{\mathrm{a}}$ & $256^{\mathrm{a}}$ & $3.07^{\mathrm{a}}$ & $40.55^{\mathrm{a}}$ \\
\hline No presalting & $182^{\mathrm{a}}$ & $75^{\mathrm{a}}$ & $258^{\mathrm{a}}$ & $2.30^{\mathrm{b}}$ & $40.73^{\mathrm{a}}$ \\
\hline LSD & NS & NS & NS & 0.09 & NS \\
\hline Saturated brine & $228^{\mathrm{a}}$ & $69^{\mathrm{b}}$ & $301^{\mathrm{a}}$ & $2.55^{\mathrm{b}}$ & $39.91^{b}$ \\
\hline $18 \%$ Brine & $136^{\mathrm{b}}$ & $81^{\mathrm{a}}$ & $213^{\mathrm{b}}$ & $2.82^{\mathrm{a}}$ & $41.37^{\mathrm{a}}$ \\
\hline LSD & 7.75 & 2.89 & 9.43 & 0.09 & 0.26 \\
\hline \multicolumn{6}{|l|}{ Saturated brine } \\
\hline Presalting & $230^{\mathrm{a}}$ & $71^{\mathrm{a}}$ & $304^{\mathrm{a}}$ & $3.00^{\mathrm{a}}$ & $39.69^{b}$ \\
\hline No presalting & $225^{\mathrm{b}}$ & $67^{\mathrm{b}}$ & $298^{\mathrm{a}}$ & $2.09^{b}$ & $40.13^{\mathrm{a}}$ \\
\hline \multicolumn{6}{|l|}{$18 \%$ brine } \\
\hline Presalting & $132^{\mathrm{b}}$ & $79^{\mathrm{b}}$ & $209^{a}$ & $3.14^{\mathrm{a}}$ & $41.41^{\mathrm{a}}$ \\
\hline No presalting & $140^{\mathrm{a}}$ & $84^{\mathrm{a}}$ & $218^{\mathrm{a}}$ & $2.50^{\mathrm{b}}$ & $41.32^{\mathrm{a}}$ \\
\hline $12^{\circ} \mathrm{C}$ & $167^{\mathrm{c}}$ & $75^{\mathrm{a}}$ & $249^{a}$ & $2.65^{\mathrm{a}}$ & $40.94^{\mathrm{a}}$ \\
\hline $15^{\circ} \mathrm{C}$ & $182^{\mathrm{b}}$ & $75^{\mathrm{a}}$ & $257^{\mathrm{a}}$ & $2.69^{\mathrm{a}}$ & $40.66^{a}$ \\
\hline $18^{\circ} \mathrm{C}$ & $197^{\mathrm{a}}$ & $76^{\mathrm{a}}$ & $266^{\mathrm{a}}$ & $2.71^{\mathrm{a}}$ & $40.32^{\mathrm{b}}$ \\
\hline LSD & 9.49 & NS & NS & NS & 0.32 \\
\hline
\end{tabular}

${ }^{a-c}$ Means within salting method, brine concentration, and brine temperature within a column not sharing the same superscript are different $(P<0.05)$.

10), with moisture difference among the BT increasing with time of brining. There was a trend for higher moisture content of the P1 portion $(P=0.01)$ for the PS cheeses, but the size of this impact (Figure 11) was small compared with the BC effect (Table 6, Figure 9).

Cheese in portion P2, left $24 \mathrm{~d}$ in $18 \% \mathrm{~B}$, (Figure 9) decreased in moisture with time of brining but the change with time was more linear than quadratic compared with the change in $\mathrm{P} 1$ (Table 5$)$. There was a $(P$ $<0.01$ ) linear interaction of time $\times \mathrm{BC}$ in portion $\mathrm{P} 2$ (Table 5, Figure 9), with cheeses kept for $24 \mathrm{~d}$ in $18 \% \mathrm{~B}$ maintaining higher moisture content (approximately $37 \%$ ) than the cheeses left in the SB (approximately

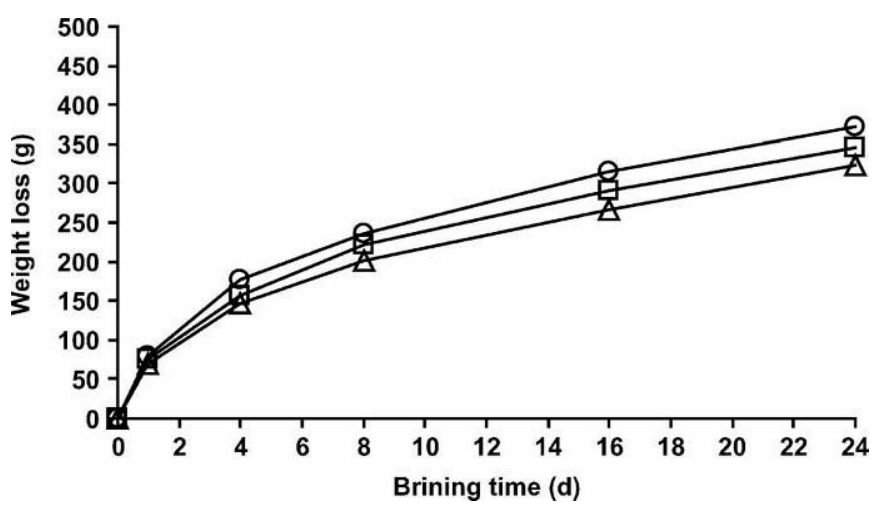

Figure 2. Impact of the interaction of time by brine temperature: $12^{\circ} \mathrm{C}(\triangle), 15^{\circ} \mathrm{C}(\square)$, and $18^{\circ} \mathrm{C}(\bigcirc)$ on total weight loss (g) in Ragusano cheese at $0,1,4,8,16$, and $24 \mathrm{~d}$ of brining.
$34 \%)$. This would produce higher porosity in the $18 \% \mathrm{~B}$ cheeses than in the SB cheeses. There was a significant effect $(P<0.01)$ of BT (Table 5), showing that at lower $\mathrm{BT}$, the P2 portion of the cheeses maintained higher moisture content at the end of $24 \mathrm{~d}$ of brining (36.3 vs. $35 \%$; Figure 10). There was also a significant interaction of BT with the time of brining $(P=0.04$; Figure 10, Table 5). In general, the absolute magnitude of the difference in moisture in P2 due to BT was smaller than in P1 (Figure 10). The effect of the PS on the moisture

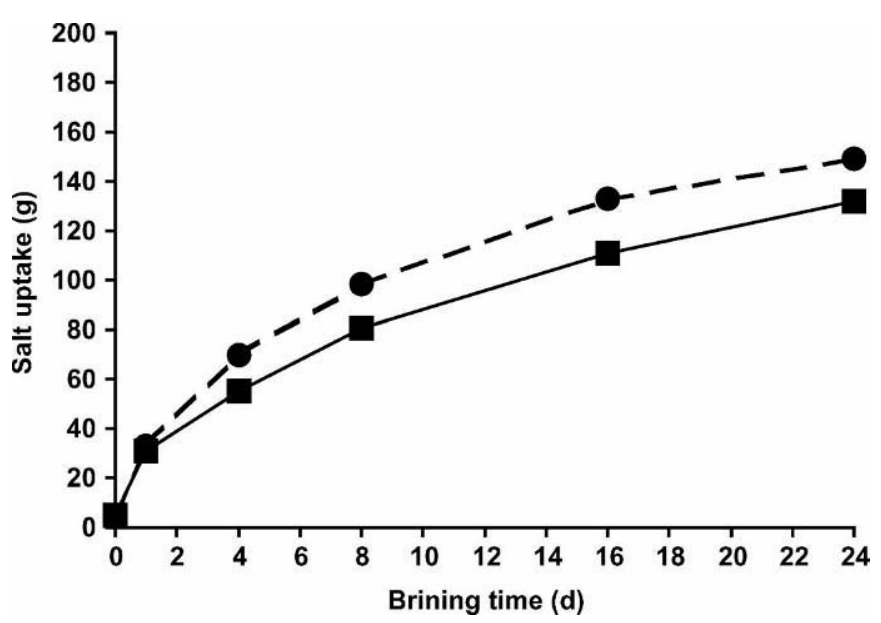

Figure 3. Impact of brine concentration, $18 \%$ brine ( ) vs. saturated brine ( $)$, on total salt uptake (g) in Ragusano cheese at 0,1 , $4,8,16$, and $24 \mathrm{~d}$ of brining. 


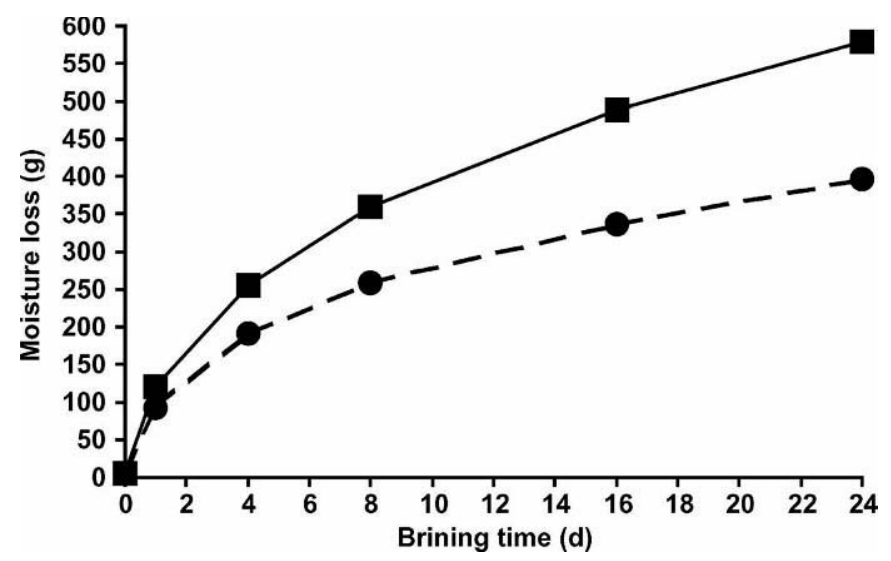

Figure 4. Impact of brine concentration, $18 \%$ brine (-) vs. saturated brine ( $\mathbf{\square})$, on total moisture loss (g) in Ragusano cheese at 0 , $1,4,8,16$, and $24 \mathrm{~d}$ of brining.

content of the P2 and P3 portions was significant (Table 5) with PS cheese having lower least squares mean moisture $(P<0.01$; Table 6$)$. The 2 -way interaction (PS $\times \mathrm{BC})$ was significant $(P<0.01)$ with PS having no impact on the least squares mean moisture within the $\mathrm{P} 2$ portion in $18 \% \mathrm{~B}$ (41.18 vs. $41.23 \%)$, but in contrast, producing lower moisture in cheeses kept in SB (39.97 vs. 40.68\%; Table 6). The same interaction was observed in portion P3. The PS cheeses may have had a slightly more porous structure (i.e., more moisture) at the exterior $1 \mathrm{~mm}$ of the surface of the block early in brining, as reported by Melilli et al. (2005), which allowed more moisture to exit from the P2 and P3 portions for the PS blocks vs. blocks that were not PS and then placed in SB. Similar impacts of BC, BT, and PS on moisture observed in $\mathrm{P} 1$ were also seen in portions $\mathrm{P} 3$ and $\mathrm{P} 4$, but the absolute magnitude of the differences in moisture became smaller in the interior portion of the blocks (Tables 5 and 6, Figures 9, 10, and 11).

Salt. There were both linear and quadratic effects of time on salt content of the cheeses in all portions (Table 7 , Figures $12,13,14)$, with salt content increasing with time of brining. The PS had the largest effect $(P<0.01)$ on the salt content in all the portions (P1, P2, P3, and $\mathrm{P} 4$; Table 7), with a higher salt content in all portions for the PS cheeses (Figure 12, Table 8). The key difference produced by PS was that the all PS cheeses started at time 0 with about $1 \%$ salt content in all portions (Figure 12). The goal of PS was to deliver a moderate amount of salt to the center of the block of cheese at time 0 with the goal of reducing early gas production by undesirable bacteria. Presalting made a large reduction in gas production and these results have been reported separately (Melilli et al., 2004b). Overall, the rate of increase in percentage salt content with time of brining was not strongly influenced by PS, when the difference in initial salt content was considered (Figure 12). The second largest impact of a main experimental treatment on salt content within the block of cheese was due to BC (Table 7) with cheeses in 18\%B achieving a higher least squares mean salt content in all portions (Table 8) and by the end of $24 \mathrm{~d}$ (Figure 13) than the cheeses in SB. There was a small impact $(P=0.01)$ of $\mathrm{BT}$ on overall salt content in portions $\mathrm{P} 3$ and P4 (Tables 7 and 8 and Figure 14). This was consistent with a previous report (Melilli et al., 2003b) that the higher the BT, the higher the salt content (Figure 14). However, although the impact of BT was significant, the absolute differences in salt content (over this small range of temperature) were not large. This does not mean BT is not important because lower BT can reduce the rate at which undesirable gas producing organisms cause gas defects (Melilli et al., 2004b). From a practical point of view, keeping the BT slightly lower (e.g., 15 instead of $18^{\circ} \mathrm{C}$ ) has the advantage of not decreasing salt uptake very much (Figure 14), but may make an important contribution to reducing gas production by undesirable microflora, as reported by Melilli et al. (2004b).

Salt in Moisture. The impact of PS on salt in moisture was significant $(P<0.01)$ in all portions (Table 9$)$, showing that PS cheeses had a higher salt in moisture content than cheeses that were NPS (Table 10, Figure 15). Cheeses that were PS contained about $2.25 \%$ salt in moisture in all portions (Figure 15) before being placed in brine, whereas cheeses that were NPS contained about $0.2 \%$ salt in moisture. Salt in moisture in the $\mathrm{P} 1$ portion became very high (about 8 to $10 \%$ ) within $24 \mathrm{~h}$ (Figure 15) after the start of brining and this is at least part of the reason why gas holes are not seen near the surface of the cheese. Looking specifically at each portion of the block, in $\mathrm{P} 1$ there was a significant effect of $\mathrm{BC}(P<0.01$; Table 9$)$, with cheeses kept in SB achieving a higher salt in moisture content in P1 (Figure 16, Table 10). The 2 treatments (SB vs. 18\%B) were about the same with respect to salt in moisture until $8 \mathrm{~d}$ in the P1 portion and then they diverged (Figure 16) as the $\mathrm{P} 1$ portion of the cheese in SB continued to increase in salt in moisture. Even though the salt in moisture was similar in the $\mathrm{P} 1$ portions of cheese in SB and 18\%B until $8 \mathrm{~d}$ of brining (Figure 16), the moisture content of the $\mathrm{P} 1$ portions were very different (Figure 9), with the cheeses in 18\%B having a much higher moisture and much more porous structure (i.e., less barrier to salt penetration) than the cheeses in SB. The more porous structure (particularly in P1) of the cheese in $18 \% \mathrm{~B}$ allowed more uptake of salt (Table 3, Figure 3$)$ and higher salt in moisture $(\mathrm{PS} \times \mathrm{BC}$ interaction; Table 9) in the interior (P2, P3, and P4) portions with time of brining (Figure 16), which was the opposite 
MELILLI ET AL.

Table 4. Salt (\%) in $24 \mathrm{~d}$ of brining time, for portions P1, P2, P3, and $\mathrm{P}^{1}$ of each treatment

\begin{tabular}{|c|c|c|c|c|c|c|c|c|}
\hline \multirow[b]{2}{*}{ Day } & \multicolumn{4}{|c|}{ Presalted cheeses } & \multicolumn{4}{|c|}{ Nonpresalted cheeses } \\
\hline & $\mathrm{P} 1$ & $\mathrm{P} 2$ & P3 & $\mathrm{P} 4$ & $\mathrm{P} 1$ & $\mathrm{P} 2$ & P3 & $\mathrm{P} 4$ \\
\hline & & & & Saturate & e at 12 & & & \\
\hline 0 & 1.03 & 1.02 & 1.00 & 1.00 & 0.07 & 0.10 & 0.10 & 0.11 \\
\hline 1 & 3.71 & 1.46 & 0.99 & 0.96 & 3.08 & 0.51 & 0.11 & 0.06 \\
\hline 4 & 4.72 & 2.45 & 1.29 & 0.95 & 3.96 & 1.68 & 0.52 & 0.12 \\
\hline 8 & 5.51 & 3.69 & 2.00 & 1.12 & 4.79 & 2.81 & 1.08 & 0.35 \\
\hline 16 & 6.05 & 4.81 & 3.12 & 1.87 & 5.12 & 3.65 & 2.18 & 0.91 \\
\hline \multirow[t]{2}{*}{24} & 6.22 & 5.15 & 3.77 & 2.37 & 6.18 & 5.16 & 3.45 & 1.83 \\
\hline & & & & \multicolumn{2}{|c|}{$18 \%$ Brine at $12^{\circ} \mathrm{C}$} & & & \\
\hline 0 & 1.03 & 1.02 & 1.00 & 1.00 & 0.07 & 0.10 & 0.10 & 0.11 \\
\hline 1 & 3.76 & 1.40 & 0.92 & 0.97 & 3.18 & 0.53 & 0.11 & 0.04 \\
\hline 4 & 5.19 & 2.79 & 1.47 & 0.98 & 4.81 & 2.12 & 0.59 & 0.14 \\
\hline 8 & 5.20 & 4.38 & 2.65 & 1.40 & 5.66 & 3.63 & 1.53 & 0.37 \\
\hline 16 & 6.26 & 5.16 & 3.57 & 1.92 & 6.23 & 4.91 & 3.20 & 1.36 \\
\hline \multirow[t]{2}{*}{24} & 6.51 & 5.67 & 4.47 & 2.84 & 6.27 & 5.22 & 3.58 & 1.81 \\
\hline & & & & \multicolumn{2}{|c|}{ Saturated brine at $15^{\circ}$} & & & \\
\hline 0 & 1.03 & 1.02 & 1.00 & 1.00 & 0.07 & 0.10 & 0.10 & 0.11 \\
\hline 1 & 3.54 & 1.42 & 0.94 & 0.88 & 2.77 & 0.51 & 0.15 & 0.78 \\
\hline 4 & 4.19 & 2.52 & 1.37 & 1.00 & 3.72 & 1.57 & 0.42 & 0.09 \\
\hline 8 & 5.60 & 3.69 & 2.29 & 1.23 & 4.40 & 2.50 & 1.17 & 0.27 \\
\hline 16 & 5.89 & 4.83 & 3.40 & 1.96 & 5.64 & 4.34 & 2.74 & 1.18 \\
\hline \multirow[t]{2}{*}{24} & 6.88 & 5.98 & 4.71 & 3.03 & 5.47 & 4.51 & 3.08 & 1.62 \\
\hline & & & & \multicolumn{2}{|c|}{$18 \%$ Brine at $15^{\circ} \mathrm{C}$} & & & \\
\hline 0 & 1.03 & 1.02 & 1.00 & 1.00 & 0.07 & 0.10 & 0.10 & 0.11 \\
\hline 1 & 3.84 & 1.46 & 0.90 & 0.90 & 3.13 & 0.55 & 0.11 & 0.08 \\
\hline 4 & 4.71 & 3.19 & 1.55 & 1.00 & 5.05 & 2.47 & 0.77 & 0.21 \\
\hline 8 & 5.73 & 4.14 & 2.58 & 1.34 & 5.59 & 3.64 & 1.71 & 0.45 \\
\hline 16 & 6.27 & 5.21 & 3.87 & 2.26 & 6.03 & 4.94 & 3.27 & 1.44 \\
\hline \multirow[t]{2}{*}{24} & 6.52 & 5.79 & 4.67 & 3.14 & 6.31 & 5.45 & 4.07 & 2.29 \\
\hline & & & & \multicolumn{2}{|c|}{ Saturated brine at $18^{\circ}$} & & & \\
\hline 0 & 1.03 & 1.02 & 1.00 & 1.00 & 0.07 & 0.10 & 0.10 & 0.11 \\
\hline 1 & 3.60 & 1.50 & 1.05 & 1.07 & 2.56 & 0.52 & 0.11 & 0.05 \\
\hline 4 & 4.43 & 2.84 & 1.51 & 0.97 & 3.96 & 1.99 & 0.65 & 0.11 \\
\hline 8 & 5.41 & 3.94 & 2.43 & 1.34 & 4.30 & 2.68 & 1.30 & 0.46 \\
\hline 16 & 5.91 & 5.01 & 3.68 & 2.23 & 5.06 & 4.15 & 2.69 & 1.13 \\
\hline \multirow[t]{2}{*}{24} & 6.28 & 5.45 & 4.90 & 3.46 & 4.94 & 4.35 & 3.04 & 1.73 \\
\hline & & & & \multicolumn{2}{|c|}{$-18 \%$ Brine at $18^{\circ} \mathrm{C}$} & & & \\
\hline 0 & 1.03 & 1.02 & 1.00 & 1.00 & 0.07 & 0.10 & 0.10 & 0.11 \\
\hline 1 & 3.80 & 1.64 & 1.06 & 1.02 & 3.36 & 0.76 & 0.12 & 0.08 \\
\hline 4 & 4.69 & 3.29 & 1.71 & 0.97 & 4.84 & 2.49 & 0.84 & 0.19 \\
\hline 8 & 5.45 & 4.14 & 2.54 & 1.26 & 5.52 & 3.78 & 1.94 & 0.53 \\
\hline 16 & 6.20 & 5.30 & 4.05 & 2.37 & 5.93 & 5.08 & 3.75 & 5.08 \\
\hline 24 & 6.39 & 5.84 & 5.00 & 3.61 & 5.69 & 4.99 & 3.81 & 2.16 \\
\hline
\end{tabular}

${ }^{1}$ Treatments: presalting the curd (presalted vs. not presalted), brine concentration (saturated vs. $18 \%$ brine), and brine temperature $\left(12,15\right.$, and $\left.18^{\circ} \mathrm{C}\right)$. Portions $\mathrm{P} 1, \mathrm{P} 2, \mathrm{P} 3$, and $\mathrm{P} 4$ represent portions of the cheese block from exterior surface (P1) to interior core (P4)

of the P1 portion in SB (Figure 16). Thus, the combination of PS plus lower BC produced a higher salt in moisture content in the interior portions (Figures 15 and 16), particularly during the first $8 \mathrm{~d}$. The $\mathrm{P} 4$ portion of the PS cheeses at d 0 had about the same salt in moisture content as a cheese that had been in SB for $16 \mathrm{~d}$ without PS. Higher salt in moisture content during the early stages of brine salting, particularly when brine temperature is $>18^{\circ} \mathrm{C}$, should help control early gas production (Melilli et al., 2003b). The main effect of BT in P1 was not significant $(P=0.59$; Tables 9 and
10); the salt in moisture content for all brine temperatures after $24 \mathrm{~d}$ of brining (Figure 17) was about $18 \%$. However, BT did have a consistent influence $(P \leq 0.05$; Tables 9 and 10) on salt in moisture in the P2, P3, and $\mathrm{P} 4$ portions with cheeses at lower BT achieving lower salt in moisture (Figure 17) after $24 \mathrm{~d}$ of brining, but the magnitude of the impact of BT on salt in moisture was very small compared with the impact of PS and $\mathrm{BC}$. This is consistent with the previous report of Melilli et al. (2003b). Decreasing BT increases the viscosity of the water phase (Walstra et al., 1999) and this would 


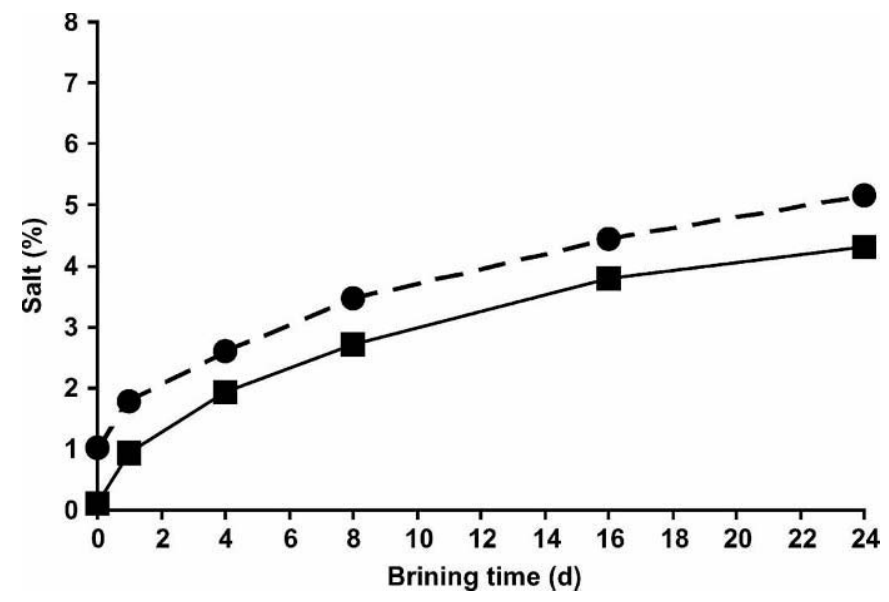

Figure 5. Impact of presalting, presalted (-) vs. not presalted (घ), on total salt content (\%) in Ragusano cheese at $0,1,4,8,16$, and $24 \mathrm{~d}$ of brining.

tend to have more impact in the interior portions of the cheese because the salt taken up from the brine has a longer distance to travel through a more viscous water phase. This is also consistent with the increasing type III sum of squares for the BT going from P1 to P4 (Table 9) and the interaction of $\mathrm{t} \times \mathrm{BT}$ for portions P3 and P4 observed in the present study. Salt in moisture content can influence gas production by undesirable microflora (Melilli et al., 2004b), proteolysis and lipolysis (Melilli et al., 2004a), growth of desirable microflora, and $\mathrm{pH}$ changes in cheese produced by desirable lactic acidproducing bacteria.

$\boldsymbol{p H}$. The impact of all treatments (i.e., PS, BC, and $\mathrm{BT})$ on cheese $\mathrm{pH}$ both initially and during time of storage was very small (usually $<0.1 \mathrm{pH}$ units). Generally, if all has gone well in cheese making, the typical $\mathrm{pH}$ of the cheese should be achieved before PS and the pasta-filata step in Ragusano cheese making (Licitra

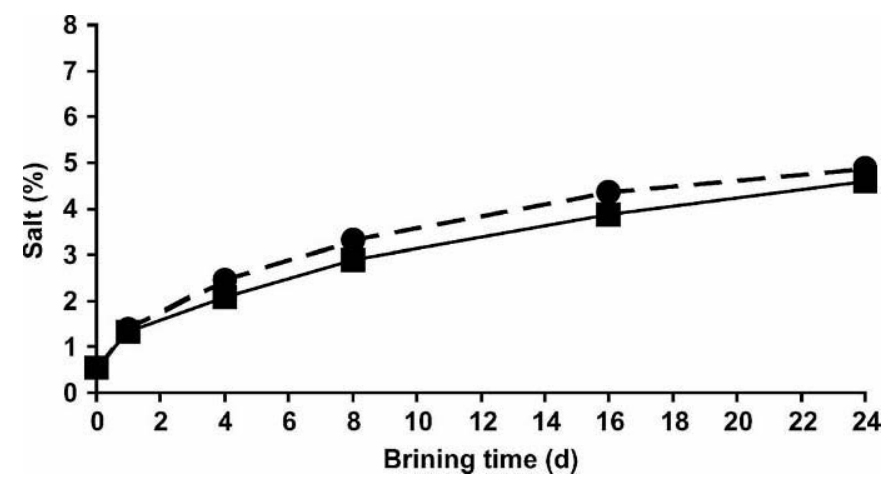

Figure 6. Impact of brine concentration, $18 \%$ brine (-) vs. saturated brine ( ), on total salt content (\%) in Ragusano cheese at 0, 1, $4,8,16$, and $24 \mathrm{~d}$ of brining.

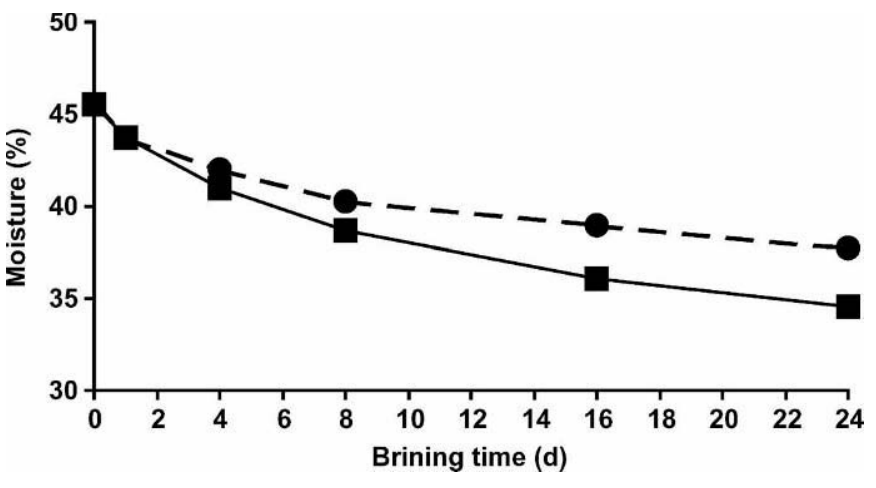

Figure 7. Impact of brine concentration, $18 \%$ brine (@) vs. saturated brine (-), on total moisture content (\%) in Ragusano cheese at $0,1,4,8,16$, and $24 \mathrm{~d}$ of brining.

et al., 1998). The $\mathrm{R}^{2}$ for the ANOVA models were low (Table 11) and the absolute impacts of the treatment parameters on cheese $\mathrm{pH}$ were small (Table 12). In the present study, the $\mathrm{pH}$ of the curd at stretching was about 5.1 to 5.3 , thus the acid development by the starter culture was completed before PS. The largest impact on $\mathrm{pH}$ of the main effects was in the $\mathrm{P} 1$ portion with PS cheese in $18 \% \mathrm{~B}$ held at the lowest temperature (i.e., $12^{\circ} \mathrm{C}$ ) having the highest $\mathrm{pH}$, but the differences were small (generally $<0.05 \mathrm{pH}$ units). Although there was an effect $(P<0.02)$ of time of brining on $\mathrm{pH}$ of the P1, P2, and P3 portions (Table 11), it explained only a very small amount of the total variation in $\mathrm{pH}$ among treatments.

\section{DISCUSSION}

\section{Factors Influencing Salt Uptake During Brining}

Salt content of cheese influences both rate of growth and type of microbial populations (both desirable and

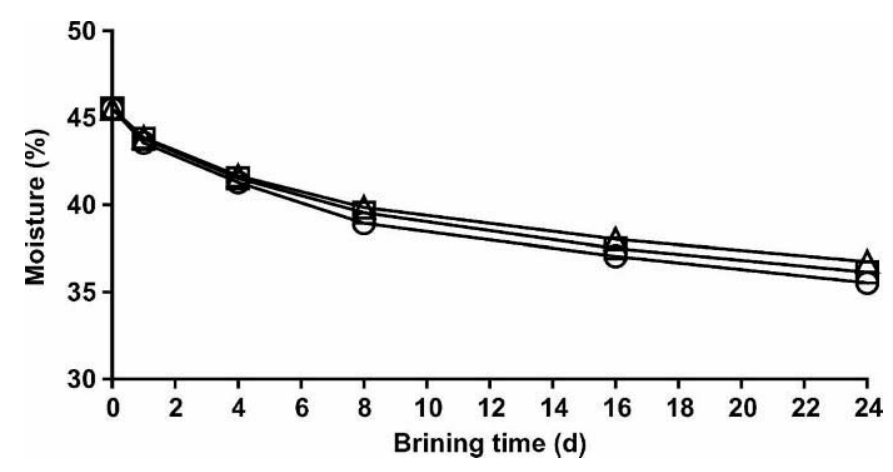

Figure 8. Impact of the interaction of time by brine temperature: $12^{\circ} \mathrm{C}(\triangle), 15^{\circ} \mathrm{C}(\square)$, and $18^{\circ} \mathrm{C}(\bigcirc)$ on total moisture content $(\mathrm{g})$ in Ragusano cheese at $0,1,4,8,16$, and $24 \mathrm{~d}$ of brining. 
MELILLI ET AL.

Table 5. Sums of the squares (Type III SS) and probability values (in parentheses) for the ANOVA of the impact of treatments ${ }^{1}$ on moisture content of cheese portions (P1, P2, P3, and P4) of Ragusano cheese at $0,1,4,8,16$, and $24 \mathrm{~d}$ of brining

\begin{tabular}{|c|c|c|c|c|c|c|c|}
\hline Factors $^{2}$ & $\mathrm{df}$ & $\mathrm{P} 1$ & $\mathrm{P} 2$ & P3 & $\mathrm{P} 4$ & Analyzed as & Error term \\
\hline \multicolumn{8}{|l|}{ Whole plot } \\
\hline $\mathrm{BC}$ & 1 & $\begin{array}{l}702.09^{*} \\
(<0.01)\end{array}$ & $\begin{array}{c}84.18^{*} \\
(<0.01)\end{array}$ & $\begin{array}{l}5.19^{*} \\
(0.01)\end{array}$ & $\begin{array}{l}1.00^{*} \\
(0.01)\end{array}$ & Category & $\mathrm{BC} \times \mathrm{BT} \times \mathrm{PS}$ \\
\hline $\mathrm{BT}$ & 2 & $\begin{array}{c}84.63^{*} \\
(<0.01)\end{array}$ & $\underset{(<0.01)}{28.31^{*}}$ & $\begin{array}{c}5.58^{*} \\
(0.01)\end{array}$ & $\begin{array}{l}3.50 * \\
(0.01)\end{array}$ & Category & $\mathrm{BC} \times \mathrm{BT} \times \mathrm{PS}$ \\
\hline PS & 1 & $\begin{array}{c}7.48^{*} \\
(0.01)\end{array}$ & $\begin{array}{c}7.85^{*} \\
(0.01)\end{array}$ & $\begin{array}{r}4.28^{*} \\
(0.01)\end{array}$ & $\begin{array}{r}3.47^{*} \\
(0.01)\end{array}$ & Category & $\mathrm{BC} \times \mathrm{BT} \times \mathrm{PS}$ \\
\hline $\mathrm{BC} \times \mathrm{PS}$ & 1 & NS & $\begin{array}{l}6.10^{*} \\
(0.01)\end{array}$ & $\begin{array}{c}3.39^{*} \\
(0.01)\end{array}$ & $\begin{array}{l}2.25^{*} \\
(0.01)\end{array}$ & Interaction & $\mathrm{BC} \times \mathrm{BT} \times \mathrm{PS}$ \\
\hline $\mathrm{BC} \times \mathrm{BT} \times \mathrm{PS}$ & 7 & $\begin{array}{c}5.10 \\
(0.99)\end{array}$ & $\begin{array}{l}1.22 \\
(0.98)\end{array}$ & $\begin{array}{c}0.15 \\
(1.00)\end{array}$ & $\begin{array}{c}0.39 \\
(1.00)\end{array}$ & Whole plot error & Model error \\
\hline \multicolumn{8}{|l|}{ Subplot } \\
\hline $\mathrm{t}$ & 1 & $\begin{array}{c}2,492.50^{*} \\
(<0.01)\end{array}$ & $\begin{array}{r}2,694.80^{*} \\
(<0.01)\end{array}$ & $\begin{array}{c}1,426.16^{*} \\
(<0.01)\end{array}$ & $\begin{array}{r}466.35^{*} \\
(0.01)\end{array}$ & Continuous & Model error \\
\hline $\mathrm{t} \times \mathrm{BC}$ & 1 & $\begin{array}{c}275.21^{*} \\
(<0.01)\end{array}$ & $\begin{array}{c}80.52^{*} \\
(<0.01)\end{array}$ & $\begin{array}{r}7.71^{*} \\
(0.01)\end{array}$ & $\mathrm{NS}$ & Interaction & Model error \\
\hline $\mathrm{t} \times \mathrm{BT}$ & 2 & $\begin{array}{r}27.78^{*} \\
(0.04)\end{array}$ & $\begin{array}{c}\text { 7.01* } \\
(0.04)\end{array}$ & NS & NS & Interaction & Model error \\
\hline $\mathrm{t} \times \mathrm{t}$ & 1 & $\begin{array}{c}967.06^{*} \\
(<0.01)\end{array}$ & $\begin{array}{c}317.19^{*} \\
(<0.01)\end{array}$ & $\begin{array}{c}24.09 * \\
(<0.01)\end{array}$ & $\begin{array}{l}3.85^{*} \\
(0.04)\end{array}$ & Continuous & Model error \\
\hline$(\mathrm{t} \times \mathrm{t}) \times \mathrm{BC}$ & 1 & $\begin{array}{r}78.28^{*} \\
(<0.01)\end{array}$ & NS & NS & NS & Interaction & Model error \\
\hline Error & 198 & 822.78 & - & - & - & & \\
\hline Error & 199 & - & 205.55 & - & - & & \\
\hline Error & 201 & - & - & 190.40 & - & & \\
\hline Error & 202 & - & - & - & 185.19 & & \\
\hline $\mathrm{R}^{2}$ & & 0.86 & 0.94 & 0.89 & 0.72 & & \\
\hline
\end{tabular}

${ }^{1}$ Treatments: presalting the curd (presalted vs. not presalted), brine concentration (saturated brine vs. $18 \%$ brine), and brine temperature $\left(12,15\right.$, and $\left.18^{\circ} \mathrm{C}\right) . \mathrm{P} 1, \mathrm{P} 2, \mathrm{P} 3$, and $\mathrm{P} 4$ represent portions of the cheese block from exterior surface (P1) to interior core (P4).

${ }^{2}$ Factors: $\mathrm{BC}=$ brine concentration; $\mathrm{BT}=$ brine temperature; $\mathrm{PS}=$ presalting; $\mathrm{t}=$ time.

*Statistically significant $(P<0.05)$.

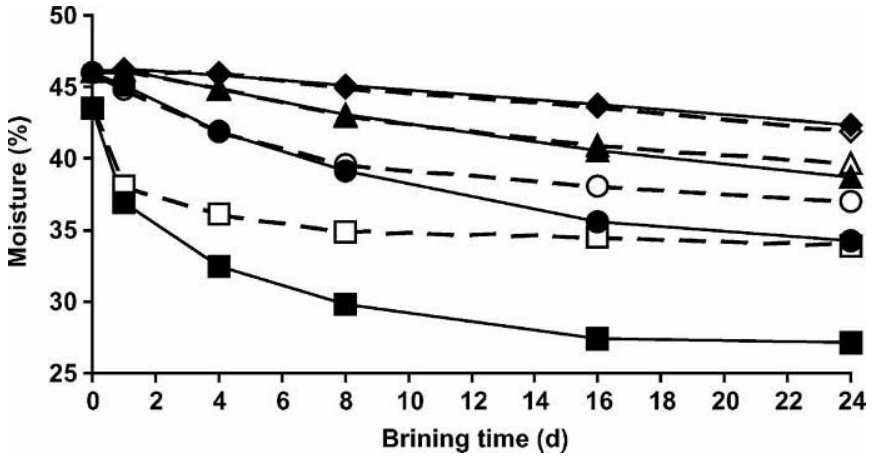

Figure 9. The impact of saturated brine (SB) vs. $18 \%$ brine $(18 \% \mathrm{~B})$ during $24 \mathrm{~d}$ of brining time on moisture content in portions $\mathrm{P} 1(\square$, 口), $\mathrm{P} 2(\mathrm{O}, \bullet), \mathrm{P} 3(\triangle, \boldsymbol{\Delta})$, and $\mathrm{P} 4(\diamond, \diamond) ; \mathrm{P} 1, \mathrm{P} 2, \mathrm{P} 3$, and $\mathrm{P} 4$ represent portions of the cheese block from exterior surface (P1) to interior core (P4). Filled symbols are cheeses in SB and open symbols are the cheeses in $18 \% \mathrm{~B}$. undesirable) that are present in cheese. In brine-salted cheeses salt diffuses slowly into the cheese and probably does not reach an inhibitory concentration in the interior until starter growth has ceased (Fox et al., 2000). Salt content also can influence partitioning of proteins and enzymes between the casein matrix and the water phase of cheese. Enzymatic reactions (e.g., proteolysis, lipolysis, oxidation, decarboxylation, deamination) that contribute to flavor development during cheese aging can be influenced by salt content. Mature brine contains solutes other than $\mathrm{NaCl}$, such as lactate, calcium, and free fatty acids. The SB used in the present study were mature brines and the $18 \% \mathrm{~B}$ were made from the SB by water dilution and then were $\mathrm{pH}$ - and calcium-adjusted before use in the experiment. During the first day of brine salting, the cheese may take up solutes other than $\mathrm{NaCl}$ from the brine into the exterior portion of the cheese. Melilli et al. (2004a) demonstrated this for the uptake of butyric acid from brine by Ragusano cheese. In cheeses where the curds are salted directly during the cheese-making process and before block formation, 
Table 6. Least squares mean values of the percentage moisture of cheese portions $^{1}$ (P1, P2, P3, and P4) of Ragusano cheese, for the presalted and not presalted cheeses at 2 brine concentrations (18\% vs. saturated), and 3 brining temperatures $\left(12,15\right.$, and $\left.18^{\circ} \mathrm{C}\right)$ averaged across $24 \mathrm{~d}$ of brining

\begin{tabular}{|c|c|c|c|c|}
\hline Variable & P1 & P2 & P3 & P4 \\
\hline Presalting & $35.04^{\mathrm{a}}$ & $40.57^{\mathrm{b}}$ & $43.19^{\mathrm{b}}$ & $44.69^{\mathrm{a}}$ \\
\hline No presalting & $34.67^{\mathrm{a}}$ & $40.96^{\mathrm{a}}$ & $43.47^{\mathrm{a}}$ & $44.95^{\mathrm{a}}$ \\
\hline LSD & NS & 0.27 & 0.26 & $\mathrm{NS}$ \\
\hline Saturated brine & $32.87^{\mathrm{b}}$ & $40.33^{\mathrm{b}}$ & $43.23^{\mathrm{a}}$ & $44.89^{\mathrm{a}}$ \\
\hline $18 \%$ Brine & $36.83^{\mathrm{a}}$ & $41.21^{\mathrm{a}}$ & $43.43^{\mathrm{a}}$ & $44.75^{\mathrm{a}}$ \\
\hline LSD & 0.55 & 0.27 & NS & NS \\
\hline \multicolumn{5}{|l|}{ Saturated brine } \\
\hline Presalting & $33.02^{\mathrm{a}}$ & $39.97^{\mathrm{b}}$ & $42.97^{\mathrm{b}}$ & $44.66^{\mathrm{b}}$ \\
\hline No presalting & $32.73^{\mathrm{a}}$ & $40.68^{\mathrm{a}}$ & $43.50^{\mathrm{a}}$ & $45.12^{\mathrm{a}}$ \\
\hline \multicolumn{5}{|l|}{$18 \%$ Brine } \\
\hline Presalting & $37.06^{\mathrm{a}}$ & $41.18^{\mathrm{a}}$ & $43.41^{\mathrm{a}}$ & $44.73^{\mathrm{a}}$ \\
\hline No presalting & $36.60^{\mathrm{a}}$ & $41.23^{\mathrm{a}}$ & $43.44^{\mathrm{a}}$ & $44.78^{\mathrm{a}}$ \\
\hline $12^{\circ} \mathrm{C}$ & $35.46^{\mathrm{a}}$ & $41.13^{\mathrm{a}}$ & $43.54^{\mathrm{a}}$ & $44.96^{\mathrm{a}}$ \\
\hline $15^{\circ} \mathrm{C}$ & $34.94^{\mathrm{a}}$ & $40.82^{\mathrm{a}}$ & $43.31^{\mathrm{ab}}$ & $44.84^{\mathrm{a}}$ \\
\hline $18^{\circ} \mathrm{C}$ & $34.16^{\mathrm{b}}$ & $40.35^{\mathrm{b}}$ & $43.15^{\mathrm{b}}$ & $44.65^{\mathrm{a}}$ \\
\hline LSD & 0.67 & 0.33 & 0.32 & NS \\
\hline
\end{tabular}

${ }^{\mathrm{a}, \mathrm{b}}$ Means within salting method, brine concentration, and brine temperature within a column not sharing the same superscript are different $(P<0.05)$.

${ }^{1}$ Portions $\mathrm{P} 1, \mathrm{P} 2, \mathrm{P} 3$, and $\mathrm{P} 4$ represent portions of the cheese block from exterior surface (P1) to interior core (P4).

the salt content of the cheese is more uniform within blocks than for brine-salted cheeses. During brine salting, large salt concentration gradients develop within blocks of cheese (Guinee and Fox, 1986). In general, the larger the block of cheese, the larger the gradient in salt content with high salt at the exterior and low salt in the center.

Salt uptake during brine salting has been studied by Geurts et al. (1974, 1980) for Gouda cheese and Resmini et al. (1974) for Parmigiano-Reggiano cheese. The

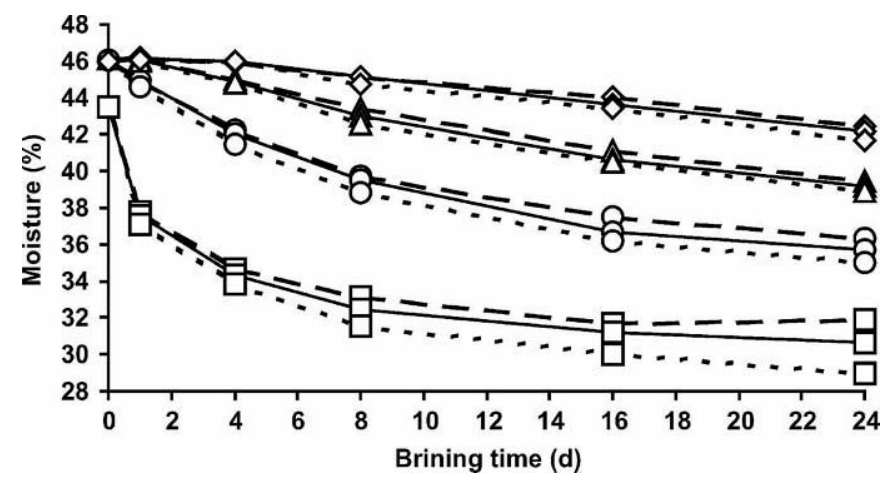

Figure 10. The impact of brine temperature (BT) during $24 \mathrm{~d}$ of brining time on moisture content in portions P1 $(\square)$, P2 $(\bigcirc)$, P3 $(\triangle)$, and $\mathrm{P} 4(\diamond) ; \mathrm{P} 1, \mathrm{P} 2, \mathrm{P} 3$, and $\mathrm{P} 4$ represent portions of the cheese block from exterior surface (P1) to interior core (P4). Dashed lines represent cheese at $12^{\circ} \mathrm{C} \mathrm{BT}$; solid lines represent cheese at $15^{\circ} \mathrm{C} \mathrm{BT}$; and dotted lines represent cheeses at $18^{\circ} \mathrm{C}$ BT.

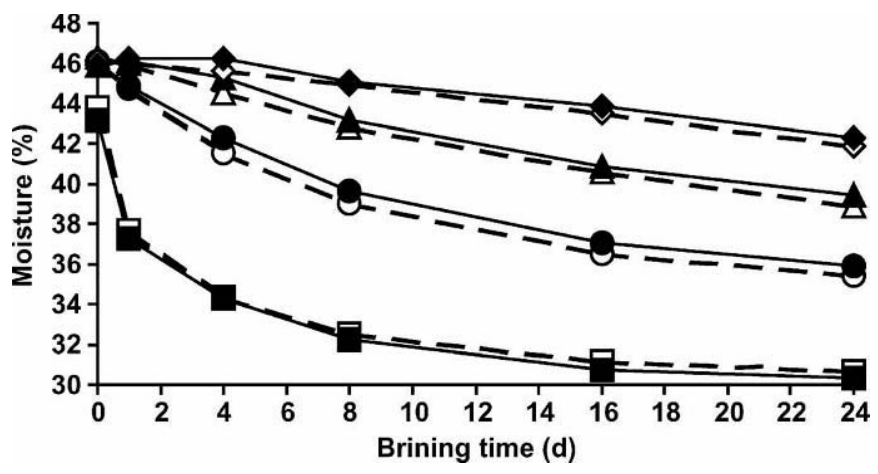

Figure 11. The impact of presalting vs. not presalting during 24 $\mathrm{d}$ of brining time on moisture content in portions $\mathrm{P} 1(\square, \mathbf{\square}), \mathrm{P} 2(\mathrm{O}$, $\bullet)$, P3 $(\triangle, \mathbf{\Delta})$, and P4 $(\diamond, \diamond)$, P1, P2, P3, and P4 represent portions of the cheese block from exterior surface (P1) to interior core (P4). Filled symbols are not presalted cheeses and open symbols are the presalted cheeses.

cheese characteristics that influence rate of penetration of salt during brine salting are: porosity of the cheese (Geurts et al., 1974), tortuosity of the channels of water within the structure (Geurts et al. 1974), the proportion of the total water that is bound, the viscosity of the free water phase (Guo et al., 1997; Payne and Morison, 1999), and the interaction of sodium with the protein matrix (Payne and Morison, 1999).

Many variables during cheese making and brining can influence salt penetration through the structure of cheese. Resmini et al. (1974) found that cheese placed in brine that was not fully saturated took up salt at a faster rate than cheese placed in SB. This was confirmed in Ragusano cheese by Melilli et al. (2003a) with cheese taking up salt faster in $18 \% \mathrm{~B}$ than SB. The moisture content of the cheeses differed greatly from the inside to the exterior surface of the block, but the cheese in $18 \% \mathrm{~B}$ had higher moisture at the exterior surface producing a more porous structure and more rapid salt penetration. During brining, cheese loses moisture into the brine and this causes the moisture content and porosity at the exterior surface of the block to decrease and form a barrier layer with lower porosity that impedes further salt penetration (Melilli et al., 2003a). Melilli et al. (2005) characterized the barrier layer in Ragusano cheese. In the $1-\mathrm{mm}$ zone at the surface of the cheese, the porosity of the cheese in SB had decreased by about 36\% after $4 \mathrm{~d}$ brining and by $50 \%$ at $12 \mathrm{~d}$ of brining, whereas cheese in $18 \% \mathrm{~B}$ had a decrease in porosity of about $23 \%$ after $4 \mathrm{~d}$ and $28 \%$ after $12 \mathrm{~d}$ of brining. Electron micrograph images presented in that study were consistent with these differences in porosity (Melilli et al., 2005). Moisture gradients from the surface to the interior of brine-salted cheeses can be very large. The exterior $1 \mathrm{~mm}$ of the 
Table 7. Sums of the squares (Type III SS) and probability values (in parentheses) for the ANOVA of the impact of treatments ${ }^{1}$ on salt content of cheese portions (P1, P2, P3, and P4) of Ragusano cheese over 24 $\mathrm{d}$ of brining

\begin{tabular}{|c|c|c|c|c|c|c|c|}
\hline Factor $^{2}$ & $\mathrm{df}$ & $\mathrm{P} 1$ & $\mathrm{P} 2$ & P3 & $\mathrm{P} 4$ & Analyzed as & Error term \\
\hline \multicolumn{8}{|l|}{ Whole plot } \\
\hline $\mathrm{BC}$ & 1 & $\begin{array}{r}8.48^{*} \\
(<0.01)\end{array}$ & $\begin{array}{r}9.82^{*} \\
(<0.01)\end{array}$ & $\begin{array}{c}5.26^{*} \\
(0.01)\end{array}$ & $\begin{array}{l}1.21^{*} \\
(0.01)\end{array}$ & Category & $\mathrm{BC} \times \mathrm{BT} \times \mathrm{PS}$ \\
\hline $\mathrm{BT}$ & 2 & $\begin{array}{c}1.11^{*} \\
(0.04)\end{array}$ & $\begin{array}{c}0.42 \\
(0.08)\end{array}$ & $\begin{array}{c}2.66^{*} \\
(0.01)\end{array}$ & $\begin{array}{l}2.00 * \\
(0.01)\end{array}$ & Category & $\mathrm{BC} \times \mathrm{BT} \times \mathrm{PS}$ \\
\hline PS & 1 & $\begin{array}{c}17.81^{*} \\
(<0.01)\end{array}$ & $\underset{(<0.01)}{26.34^{*}}$ & $\begin{array}{l}42.07 * \\
(<0.01)\end{array}$ & $\begin{array}{c}10.68^{*} \\
(<0.01)\end{array}$ & Category & $\mathrm{BC} \times \mathrm{BT} \times \mathrm{PS}$ \\
\hline $\mathrm{BC} \times \mathrm{PS}$ & 1 & $\begin{array}{c}3.47^{*} \\
(0.01)\end{array}$ & $\begin{array}{c}1.04^{*} \\
(0.01)\end{array}$ & NS & NS & Interaction & $\mathrm{BC} \times \mathrm{BT} \times \mathrm{PS}$ \\
\hline $\mathrm{BC} \times \mathrm{BT} \times \mathrm{PS}$ & 7 & $\begin{array}{c}0.61 \\
(0.99)\end{array}$ & $\begin{array}{c}0.31 \\
(0.90)\end{array}$ & $\begin{array}{c}0.94 \\
(0.19)\end{array}$ & $\begin{array}{c}0.63 \\
(0.24)\end{array}$ & $\begin{array}{l}\text { Whole plot } \\
\text { error }\end{array}$ & Model error \\
\hline \multicolumn{8}{|l|}{ Subplot } \\
\hline $\mathrm{t}$ & 1 & $\begin{array}{l}439.09^{*} \\
(<0.01)\end{array}$ & $\begin{array}{c}571.40^{*} \\
(<0.01)\end{array}$ & $\begin{array}{c}377.08^{*} \\
(<0.01)\end{array}$ & $\begin{array}{l}113.93^{*} \\
(<0.01)\end{array}$ & Continuous & Model error \\
\hline $\mathrm{t} \times \mathrm{BC}$ & 1 & NS & $\begin{array}{c}0.65^{*} \\
(0.03)\end{array}$ & $\begin{array}{r}1.83^{*} \\
(<0.01)\end{array}$ & $\begin{array}{c}1.13^{*} \\
(<0.01)\end{array}$ & Interaction & Model error \\
\hline $\mathrm{t} \times \mathrm{PS}$ & 1 & NS & $\begin{array}{r}0.60^{*} \\
(0.04)\end{array}$ & NS & $\begin{array}{c}0.50^{*} \\
(0.01)\end{array}$ & Interaction & Model error \\
\hline $\mathrm{t} \times \mathrm{BT}$ & 2 & NS & NS & $\begin{array}{r}0.94^{*} \\
(0.01)\end{array}$ & $\begin{array}{c}1.43^{*} \\
(<0.01)\end{array}$ & Interaction & Model error \\
\hline $\mathrm{t} \times \mathrm{BT} \times \mathrm{PS}$ & 2 & NS & NS & NS & $\begin{array}{c}0.54^{*} \\
(0.02)\end{array}$ & Interaction & Model error \\
\hline $\mathrm{t} \times \mathrm{t}$ & 1 & $\begin{array}{c}160.66^{*} \\
(<0.01)\end{array}$ & $\begin{array}{c}67.60^{*} \\
(<0.01)\end{array}$ & $\begin{array}{r}3.98^{*} \\
(<0.01)\end{array}$ & $\begin{array}{r}3.01^{*} \\
(<0.01)\end{array}$ & Continuous & Model error \\
\hline$(\mathrm{t} \times \mathrm{t}) \times \mathrm{BC}$ & 1 & NS & $\begin{array}{r}2.77^{*} \\
(<0.01)\end{array}$ & $\begin{array}{c}1.12^{*} \\
(0.01)\end{array}$ & NS & Interaction & Model error \\
\hline$(\mathrm{t} \times \mathrm{t}) \times \mathrm{PS}$ & 1 & NS & NS & NS & $\begin{array}{r}0.27^{*} \\
(0.05)\end{array}$ & Interaction & Model error \\
\hline Error & 202 & 175.58 & - & - & - & & \\
\hline Error & 199 & - & 27.74 & - & - & & \\
\hline Error & 198 & - & - & 18.50 & - & & \\
\hline $\begin{array}{l}\text { Error } \\
\mathrm{R}^{2}\end{array}$ & 195 & - & - & - & 13.31 & & \\
\hline $\mathrm{R}^{2}$ & & 0.79 & 0.96 & 0.96 & 0.92 & & \\
\hline
\end{tabular}

${ }^{1}$ Treatments: presalting the curd (presalted vs. not presalted), brine concentration (saturated brine vs. $18 \%$ brine), and brine temperature $\left(12,15\right.$, and $\left.18^{\circ} \mathrm{C}\right) . \mathrm{P} 1, \mathrm{P} 2, \mathrm{P} 3$, and $\mathrm{P} 4$ represent portions of the cheese block from exterior surface (P1) to interior core (P4).

${ }^{2}$ Factors: $\mathrm{BC}=$ brine concentration; $\mathrm{BT}=$ brine temperature; $\mathrm{PS}=$ presalting; $\mathrm{t}=$ time.

*Statistically significant $(P<0.05)$.

block had a moisture content of $42 \%$ in cheese before brining but was $28 \%$ after $12 \mathrm{~d}$ in $18 \% \mathrm{~B}$, whereas the moisture was only $20 \%$ after $12 \mathrm{~d}$ in SB, producing a large difference in porosity (Melilli et al., 2005) and shrinkage of the structure (Melilli et al., 2003a). Shrinkage of the cheese structure takes place at the exterior surface and has been reported by Payne and Morison (1999) and Geurts et al. (1980).

Presalting of Ragusano cheese was explored as an approach to achieve higher salt content in the interior of brine-salted cheese early in the brining process with the goal of reducing early gas formation. This approach was used successfully in Ragusano cheese and delivered $60 \%$ of the salt to the center of a block at the beginning of brine salting, without reducing the subsequent up- take of salt during brine salting of the presalted cheese (Melilli et al., 2003a). Presalting achieved about 2 to $2.5 \%$ salt in the water phase of the cheese, but this is low compared with the concentration of salt in brines; therefore, the presalting had very little impact on salt uptake from 18\%B or SB (Melilli et al., 2003a).

Turhan and Kaletunç (1992) reported that BT (4, 12.5 , and $20^{\circ} \mathrm{C}$ ) had a significant impact on salt penetration with lower BT producing slower salt penetration. Resmini et al. (1974) found that blocks of ParmigianoReggiano cheese absorbed more salt at higher brine temperature $\left(18\right.$ to $\left.20^{\circ} \mathrm{C}\right)$ than at lower temperature $\left(12.5\right.$ to $\left.13^{\circ} \mathrm{C}\right)$. Melilli et al. $(2003 \mathrm{~b})$ reported that the uptake of salt by Ragusano cheese was faster with increasing (12 to $24^{\circ} \mathrm{C}$ ) $\mathrm{BT}$, but that the rate of change 


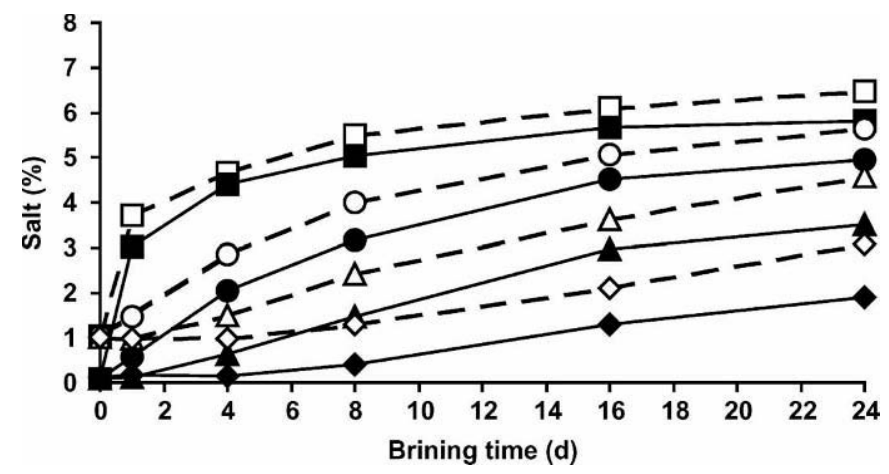

Figure 12. The impact of presalting vs. not presalting during 24 $\mathrm{d}$ of brining time on salt content $(\%)$ in portions $\mathrm{P} 1(\square, \mathbf{0}), \mathrm{P} 2(\bigcirc$, ๑), P3 $(\triangle, \mathbf{\Delta})$, and P4 $(\diamond, \diamond)$; P1, P2, P3, and P4 represent portions of the cheese block from exterior surface (P1) to interior core (P4), Filled symbols are not presalted cheeses and open symbols are the presalted cheeses in $18 \%$ brine.

of salt penetration as a function of increasing BT was not linear across this range of temperatures. Viscosity of the water phase is temperature dependent with lower temperatures favoring higher viscosity (Walstra et al., 1999) and this is consistent with slower salt penetration at lower temperatures.

The slower rate of salt penetration at lower BT was reported to be due to the increased viscosity of the water phase of cheese with decreasing temperature (Melilli et al., 2003b). There also may be a movement of casein from the protein matrix into solution in the water phase of the cheese with decreasing BT due to reduced hydrophobic attractions among the caseins. Increased casein concentration in the water phase would also cause increased viscosity and would increase resistance to salt movement in the water phase. Guo et al. (1997)

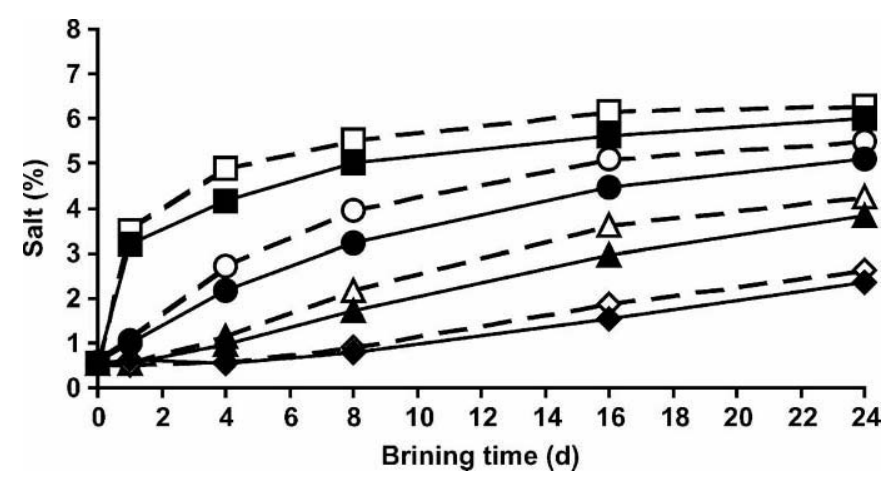

Figure 13. The impact of saturated brine (SB) vs. $18 \%$ brine $(18 \% \mathrm{~B})$ during $24 \mathrm{~d}$ of brining time on salt content $(\%)$ in portions P1 ( $\square, \mathbf{\square})$, P2 $(\bigcirc, \bullet)$, P3 $(\triangle, \mathbf{\Delta})$, and P4 ( $\diamond, \diamond)$; P1, P2, P3, and P4 represent portions of the cheese block from exterior surface (P1) to interior core (P4). Filled symbols are cheeses in SB and open symbols are the cheeses in $18 \% \mathrm{~B}$.

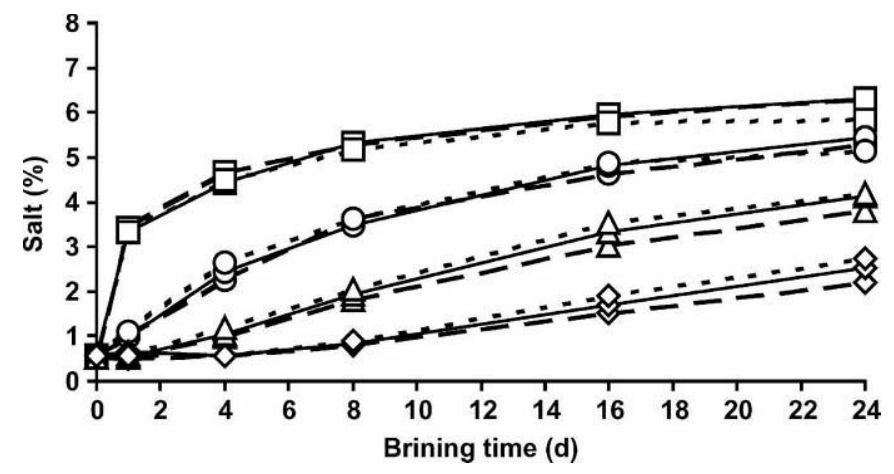

Figure 14. The impact of brine temperature (BT) during $24 \mathrm{~d}$ of brining time on salt content in portions P1 $(\square)$, P2 $(\bigcirc)$, P3 $(\triangle)$, and $\mathrm{P} 4(\diamond) ; \mathrm{P} 1, \mathrm{P} 2, \mathrm{P} 3$, and $\mathrm{P} 4$ represent portions of the cheese block from exterior surface (P1) to interior core (P4). Dashed lines represent cheese at $12^{\circ} \mathrm{C} \mathrm{BT}$; solid lines represent cheese at $15^{\circ} \mathrm{C} \mathrm{BT}$; and dotted lines represent cheeses at $18^{\circ} \mathrm{C} \mathrm{BT}$.

reported that the protein content of the expressible serum of Mozzarella increased with time of storage and salt content from $3 \%$ to $10 \% \mathrm{CP}$ over $10 \mathrm{~d}$ of storage at $4^{\circ} \mathrm{C}$ and this would be expected to increase the viscosity of the water phase of cheese.

\section{Interactions of Factors Influencing Salt Uptake}

Typically, effects of PS, BC, and BT on the uptake of salt from brine have been studied separately and

Table 8. Least squares mean values of the percentage salt of cheese portions (P1, P2, P3, and P4) ${ }^{1}$ of Ragusano cheese, for the presalted and not presalted cheeses at 2 brine concentrations (18\% vs. saturated), and 3 brining temperatures $\left(12,15\right.$, and $\left.18^{\circ} \mathrm{C}\right)$ at $0,1,4,8$, 16 , and $24 \mathrm{~d}$ of brining

\begin{tabular}{lllll}
\hline Variable & P1 & P2 & P3 & P4 \\
\hline Presalting & $4.57^{\mathrm{a}}$ & $3.34^{\mathrm{a}}$ & $2.35^{\mathrm{a}}$ & $1.57^{\mathrm{a}}$ \\
No presalting & $4.00^{\mathrm{b}}$ & $2.56^{\mathrm{b}}$ & $1.46^{\mathrm{b}}$ & $0.68^{\mathrm{b}}$ \\
LSD & 0.25 & 0.10 & 0.08 & 0.07 \\
Saturated brine & $4.09^{\mathrm{b}}$ & $2.75^{\mathrm{b}}$ & $1.76^{\mathrm{b}}$ & $1.07^{\mathrm{b}}$ \\
18\% Brine & $4.48^{\mathrm{a}}$ & $3.15^{\mathrm{a}}$ & $2.05^{\mathrm{a}}$ & $1.17^{\mathrm{a}}$ \\
LSD & 0.25 & 0.10 & 0.08 & 0.07 \\
Saturated brine & & & & \\
Presalting & $4.50^{\mathrm{a}}$ & $3.21^{\mathrm{a}}$ & $2.25^{\mathrm{a}}$ & $1.53^{\mathrm{a}}$ \\
No presalting & $3.67^{\mathrm{b}}$ & $2.29^{\mathrm{b}}$ & $1.28^{\mathrm{b}}$ & $0.61^{\mathrm{b}}$ \\
18\% Brine & & & & \\
Presalting & $4.65^{\mathrm{a}}$ & $3.47^{\mathrm{a}}$ & $2.45^{\mathrm{a}}$ & $1.61^{\mathrm{a}}$ \\
No presalting & $4.32^{\mathrm{b}}$ & $2.83^{\mathrm{b}}$ & $1.65^{\mathrm{b}}$ & $0.74^{\mathrm{b}}$ \\
$12^{\circ} \mathrm{C}$ & $4.36^{\mathrm{a}}$ & $2.89^{\mathrm{a}}$ & $1.78^{\mathrm{b}}$ & $1.02^{\mathrm{b}}$ \\
$15^{\circ} \mathrm{C}$ & $4.31^{\mathrm{a}}$ & $2.96^{\mathrm{a}}$ & $1.92^{\mathrm{a}}$ & $1.14^{\mathrm{a}}$ \\
$18^{\circ} \mathrm{C}$ & $4.19^{\mathrm{a}}$ & $3.00^{\mathrm{a}}$ & $2.02^{\mathrm{a}}$ & $1.20^{\mathrm{a}}$ \\
LSD & $\mathrm{NS}^{\mathrm{a}}$ & $\mathrm{NS}$ & 0.10 & 0.09 \\
\hline
\end{tabular}

${ }^{\mathrm{a}, \mathrm{b}}$ Means within salting method, brine concentration, and brine temperature not sharing the same superscript within a column are different $(P<0.05)$.

${ }^{1}$ Portions P1, P2, P3, and P4 represent portions of the cheese block from exterior surface (P1) to interior core (P4). 
Table 9. Sums of the squares (Type III SS) and probability values (in parentheses) for the ANOVA of the impact of treatments ${ }^{1}$ on salt in moisture content of cheese portions (P1, P2, P3, and P4) of Ragusano cheese over $24 \mathrm{~d}$ of brining

\begin{tabular}{|c|c|c|c|c|c|c|c|}
\hline Factor $^{2}$ & $\mathrm{df}$ & $\mathrm{P} 1$ & P2 & P3 & $\mathrm{P} 4$ & Analyzed as & Error term \\
\hline \multicolumn{8}{|l|}{ Whole plot } \\
\hline $\mathrm{BC}$ & 1 & $\begin{array}{c}116.88^{*} \\
(<0.01)\end{array}$ & $\begin{array}{c}39.53^{*} \\
(<0.01)\end{array}$ & $\begin{array}{l}27.97^{*} \\
(0.01)\end{array}$ & $\begin{array}{l}6.98^{*} \\
(0.01)\end{array}$ & Category & $\mathrm{BC} \times \mathrm{BT} \times \mathrm{PS}$ \\
\hline BT & 2 & $\begin{array}{c}1.09 \\
(0.59)\end{array}$ & $\begin{array}{c}8.69^{*} \\
(0.01)\end{array}$ & $\begin{array}{l}19.92^{*} \\
(0.05)\end{array}$ & $\begin{array}{l}12.70^{*} \\
(0.01)\end{array}$ & Category & $\mathrm{BC} \times \mathrm{BT} \times \mathrm{PS}$ \\
\hline PS & 1 & $\begin{array}{c}134.03^{*} \\
(<0.01)\end{array}$ & $\begin{array}{c}223.29 * \\
(<0.01)\end{array}$ & $\begin{array}{c}228.05^{*} \\
(<0.01)\end{array}$ & $\begin{array}{c}55.14^{*} \\
(<0.01)\end{array}$ & Category & $\mathrm{BC} \times \mathrm{BT} \times \mathrm{PS}$ \\
\hline $\mathrm{BC} \times \mathrm{PS}$ & 1 & $\begin{array}{c}45.89^{*} \\
(0.01)\end{array}$ & $\begin{array}{c}12.18^{*} \\
(0.01)\end{array}$ & NS & NS & Interaction & $\mathrm{BC} \times \mathrm{BT} \times \mathrm{PS}$ \\
\hline $\mathrm{BC} \times \mathrm{BT} \times \mathrm{PS}$ & 7 & $\begin{array}{c}5.69 \\
(0.99)\end{array}$ & $\begin{array}{c}2.47 \\
(0.88)\end{array}$ & $\begin{array}{l}15.10^{*} \\
(0.01)\end{array}$ & $\begin{array}{c}3.87 \\
(0.16)\end{array}$ & $\begin{array}{l}\text { Whole plot } \\
\text { error }\end{array}$ & Model error \\
\hline \multicolumn{8}{|l|}{ Subplot } \\
\hline $\mathrm{t}$ & 1 & $\begin{array}{c}6,070.95^{*} \\
(<0.01)\end{array}$ & $\begin{array}{c}4,969.71^{*} \\
(<0.01)\end{array}$ & $\begin{array}{c}2,579.20^{*} \\
\quad(<0.01)\end{array}$ & $\begin{array}{l}671.92^{*} \\
(<0.01)\end{array}$ & Continuous & Model error \\
\hline $\mathrm{t} \times \mathrm{BC}$ & 1 & $\begin{array}{c}130.53^{*} \\
(<0.01)\end{array}$ & NS & $\begin{array}{c}6.82^{*} \\
(0.01)\end{array}$ & $\begin{array}{c}6.70^{*} \\
(<0.01)\end{array}$ & Interaction & Model error \\
\hline $\mathrm{t} \times \mathrm{BT}$ & 2 & NS & NS & $\begin{array}{l}8.00 * \\
(0.01)\end{array}$ & $\begin{array}{r}9.40^{*} \\
(<0.01)\end{array}$ & Interaction & Model error \\
\hline $\mathrm{t} \times \mathrm{PS}$ & 1 & NS & NS & $\begin{array}{l}3.35^{*} \\
(0.02)\end{array}$ & $\begin{array}{c}5.47^{*} \\
(0.01)\end{array}$ & Interaction & Model error \\
\hline $\mathrm{t} \times \mathrm{BT} \times \mathrm{PS}$ & 2 & NS & NS & $\begin{array}{l}4.92 * \\
(0.02)\end{array}$ & $\begin{array}{c}3.29^{*} \\
(0.01)\end{array}$ & Interaction & Model error \\
\hline $\mathrm{t} \times \mathrm{BC} \times \mathrm{BT} \times \mathrm{PS}$ & 2 & NS & NS & $\begin{array}{l}8.13^{*} \\
(0.02)\end{array}$ & NS & Interaction & Model error \\
\hline $\mathrm{t} \times \mathrm{t}$ & 1 & $\begin{array}{c}1,619.07^{*} \\
(<0.01)\end{array}$ & $\begin{array}{c}384.74^{*} \\
(<0.01)\end{array}$ & $\begin{array}{c}10.50^{*} \\
(<0.01)\end{array}$ & $\begin{array}{c}21.51^{*} \\
(<0.01)\end{array}$ & Continuous & Model error \\
\hline$(\mathrm{t} \times \mathrm{t}) \times \mathrm{BC}$ & 1 & NS & $\begin{array}{c}19.61^{*} \\
(<0.01)\end{array}$ & $\begin{array}{c}7.62^{*} \\
(0.01)\end{array}$ & NS & Interaction & Model error \\
\hline$(\mathrm{t} \times \mathrm{t}) \times \mathrm{PS}$ & 1 & NS & NS & NS & $\begin{array}{l}1.76^{*} \\
(0.03)\end{array}$ & Interaction & Model error \\
\hline Error & 201 & $1,337.18$ & 211.11 & - & - & & \\
\hline Error & 190 & - & - & 110.97 & - & & \\
\hline $\begin{array}{l}\text { Error } \\
R^{2}\end{array}$ & 195 & - $_{087}$ & - & - & 70.06 & & \\
\hline & & 0.87 & 0.97 & 0.96 & 0.93 & & \\
\hline
\end{tabular}

${ }^{1}$ Treatments: presalting the curd (presalted vs. not presalted), brine concentration (saturated brine vs. $18 \%$ brine), and brine temperature $\left(12,15\right.$, and $\left.18^{\circ} \mathrm{C}\right) . \mathrm{P} 1, \mathrm{P} 2, \mathrm{P} 3$, and $\mathrm{P} 4$ represent portions of the cheese block from exterior surface (P1) to interior core (P4).

${ }^{2}$ Factors: $\mathrm{BC}=$ brine concentration; $\mathrm{BT}=$ brine temperature $\mathrm{PS}=$ presalting; $\mathrm{t}=$ time.

*Statistically significant $(P<0.05)$.

possible interactions of these factors are not well characterized. Our study was designed to characterize the interactions of these factors. Although presalting the curd before brining was very effective at delivering a starting salt in moisture of about $2.5 \%$ to all locations within the block of cheese before brining (Figure 15), PS did not produce any large differences in moisture content (Table 6) and therefore had only a small impact on cheese porosity and rate of salt uptake from brine (Figure 12). This is consistent with previous reported results on PS (Melilli et al., 2003a). The PS cheeses achieved a desired final salt content sooner than cheeses that were not PS. No interaction effects of PS with BT on moisture (Table 5), salt (Table 7), or salt in moisture (Table 9) content of cheese were found. However, interactions of PS with BC were observed. The PS cheeses lost more weight and took up more salt in SB, whereas the opposite was true in $18 \% \mathrm{~B}$ (Table 3 ). There was a small but significant effect of the interaction of BC and PS on total cheese moisture content (Table 2), with PS cheeses having slightly lower moisture content in SB than cheeses that were not PS (Table 3). This same effect of PS was not observed to the same extent in the cheeses in 18\% B (Table 3). The BC and PS interaction was more apparent when the moisture content by portion was observed (Tables 5 and 6 ) with PS cheeses in SB having lower moisture than cheeses that were not presalted, particularly in the interior (i.e., 
Table 10. Least squares mean values of the percentage salt in moisture of cheese portions (P1, P2, P3, and P4) $)^{1}$ of Ragusano cheese, for the presalted and not presalted cheeses at 2 brine concentrations (18\% vs. saturated), and 3 brining temperatures $\left(12,15\right.$, and $18^{\circ} \mathrm{C}$ ) at $0,1,4,8,16$, and $24 \mathrm{~d}$ of brining

\begin{tabular}{lclll}
\hline Variable & P1 & P2 & P3 & P4 \\
\hline Presalting & $13.99^{\mathrm{a}}$ & $8.74^{\mathrm{a}}$ & $5.66^{\mathrm{a}}$ & $3.58^{\mathrm{a}}$ \\
No presalting & $12.41^{\mathrm{b}}$ & $6.71^{\mathrm{b}}$ & $3.57^{\mathrm{b}}$ & $1.56^{\mathrm{b}}$ \\
LSD & 0.69 & 0.27 & 0.20 & 0.16 \\
Saturated brine & $13.70^{\mathrm{a}}$ & $7.41^{\mathrm{b}}$ & $4.31^{\mathrm{b}}$ & $2.44^{\mathrm{b}}$ \\
$18 \%$ Brine & $12.70^{\mathrm{b}}$ & $8.05^{\mathrm{a}}$ & $4.92^{\mathrm{a}}$ & $2.69^{\mathrm{a}}$ \\
LSD & 0.69 & 0.27 & 0.20 & 0.16 \\
Saturated brine & & & & \\
$\quad$ Presalting & $14.95^{\mathrm{a}}$ & $8.66^{\mathrm{a}}$ & $5.49^{\mathrm{a}}$ & $3.48^{\mathrm{a}}$ \\
No presalting & $12.45^{\mathrm{b}}$ & $6.15^{\mathrm{b}}$ & $3.12^{\mathrm{b}}$ & $1.40^{\mathrm{b}}$ \\
18\% brine & & & & \\
Presalting & $13.03^{\mathrm{a}}$ & $8.83^{\mathrm{a}}$ & $5.84^{\mathrm{a}}$ & $3.67^{\mathrm{a}}$ \\
No presalting & $12.37^{\mathrm{b}}$ & $7.27^{\mathrm{b}}$ & $4.01^{\mathrm{b}}$ & $1.71^{\mathrm{b}}$ \\
$12^{\circ} \mathrm{C}$ & $13.10^{\mathrm{a}}$ & $7.47^{\mathrm{b}}$ & $4.29^{\mathrm{c}}$ & $2.32^{\mathrm{b}}$ \\
$15^{\circ} \mathrm{C}$ & $13.24^{\mathrm{a}}$ & $7.75^{\mathrm{a}, \mathrm{b}}$ & $4.65^{\mathrm{b}}$ & $2.61^{\mathrm{a}}$ \\
$18^{\circ} \mathrm{C}$ & $13.26^{\mathrm{a}}$ & $7.96^{\mathrm{a}}$ & $4.91^{\mathrm{a}}$ & $2.77^{\mathrm{a}}$ \\
LSD & 0.85 & 0.34 & 0.25 & 0.20 \\
\hline
\end{tabular}

${ }^{\mathrm{a}-\mathrm{c}}$ Means within salting method, brine concentration, and brine temperature not sharing the same superscript within a column are different $(P<0.05)$.

${ }^{1}$ Portions $\mathrm{P} 1, \mathrm{P} 2, \mathrm{P} 3$, and $\mathrm{P} 4$ represent portions of the cheese block from exterior surface (P1) to interior core (P4).

P2, P3) of the block (Table 6). The difference in salt content and salt in moisture between the cheeses that were PS and those that were not was much larger for the $\mathrm{P} 1$ and $\mathrm{P} 2$ portions of cheeses in SB than in $18 \% \mathrm{~B}$ (Tables 8 and 10). Although the BC, BT, and PS each have their own impacts on salt uptake, there was not much interaction of these effects when they were used in combination.

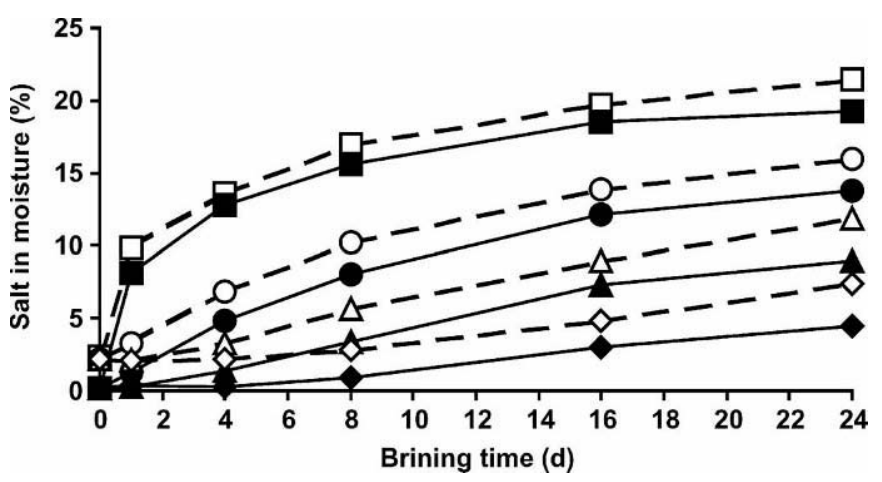

Figure 15. The impact of presalting vs. not presalting during 24 $\mathrm{d}$ of brining time on salt in moisture content $(\%)$ in portions $\mathrm{P} 1$ ( $\square$, - $)$, P2 $(\bigcirc, \bullet), \mathrm{P} 3(\triangle, \boldsymbol{\Delta})$, and $\mathrm{P} 4(\diamond, \diamond)$; P1, P2, P3, and P4 represent portions of the cheese block from exterior surface (P1) to interior core (P4). Filled symbols are not presalted cheeses and open symbols are the presalted cheeses in $18 \%$ brine.

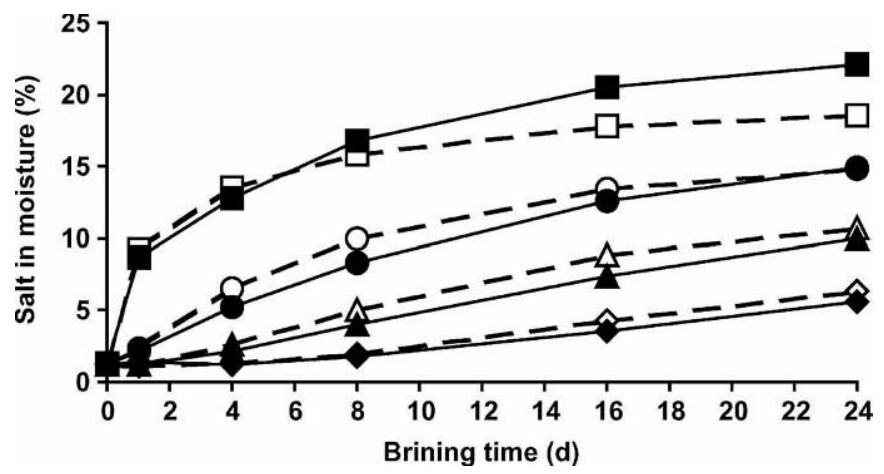

Figure 16. The impact of saturated brine (SB) vs. $18 \%$ brine $(18 \% \mathrm{~B})$ during $24 \mathrm{~d}$ of brining time on salt in moisture content (\%) in portions $\mathrm{P} 1(\square, \boldsymbol{\square}), \mathrm{P} 2(\bigcirc, \bullet), \mathrm{P} 3(\triangle, \mathbf{\Delta})$, and $\mathrm{P} 4(\diamond, \diamond)$; P1, P2, $\mathrm{P} 3$, and $\mathrm{P} 4$ represent portions of the cheese block from exterior surface (P1) to interior core (P4). Filled symbols are cheeses in SB and open symbols are the cheeses in $18 \% \mathrm{~B}$.

\section{Interactions of Factors Influencing Moisture and Cheese Yield}

During brine salting, blocks of cheese increase in weight due to salt uptake and decrease in weight due to moisture loss. In net, Ragusano cheese loses weight during brine salting (Tables 2 and 3, Figure 1) so moisture loss is larger than salt uptake (Table 3); this has a negative impact on cheese yield. There was an impact of the interaction $\mathrm{BC} \times \mathrm{PS}$ on moisture content of the P2, P3, and P4 portions of the block (Table 5), with PS cheeses maintaining higher moisture in $18 \% \mathrm{~B}$ than in SB (Table 6). This provides a larger volume of cheese within each block that has a composition similar to that in the center of block where the sensory quality is considered the best. It would be desirable to select salting conditions that favor minimization of cheese yield

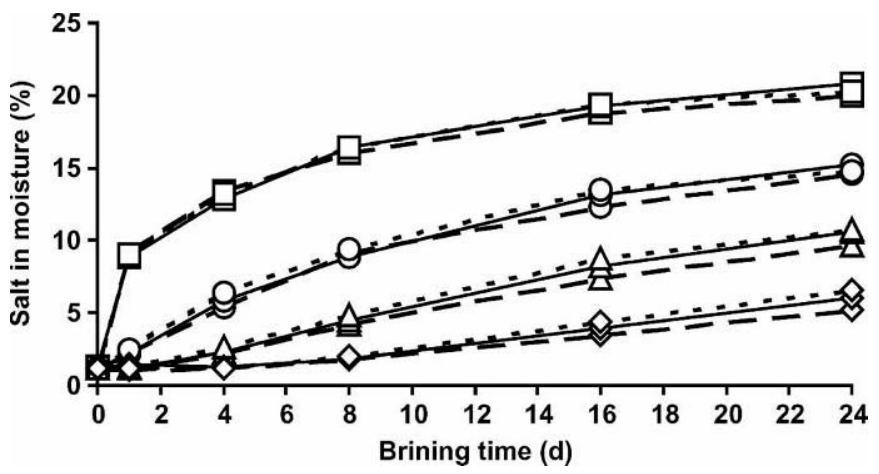

Figure 17. The impact of brine temperature (BT) during $24 \mathrm{~d}$ of brining time on salt in moisture content in portions $\mathrm{P} 1(\square), \mathrm{P} 2(\bigcirc)$, P3 $(\triangle)$, and P4 $(\diamond) ; \mathrm{P} 1, \mathrm{P} 2, \mathrm{P} 3$, and P4 represent portions of the cheese block from exterior surface (P1) to interior core (P4). Dashed lines represent cheese at $12^{\circ} \mathrm{C} \mathrm{BT}$; solid lines represent cheese at $15^{\circ} \mathrm{C} \mathrm{BT}$; and dotted lines represent cheeses at $18^{\circ} \mathrm{C}$ BT. 
Table 11. Sums of the squares (Type III SS) and probability values (in parentheses) for the ANOVA of the impact of treatments ${ }^{1}$ on $\mathrm{pH}$ of cheese portions (P1, P2, P3, and P4) of Ragusano cheese over $24 \mathrm{~d}$ of brining

\begin{tabular}{|c|c|c|c|c|c|c|c|}
\hline Factor $^{2}$ & $\mathrm{df}$ & $\mathrm{P} 1$ & $\mathrm{P} 2$ & P3 & $\mathrm{P} 4^{3}$ & Analyzed as & Error term \\
\hline \multicolumn{8}{|l|}{ Whole plot } \\
\hline $\mathrm{BC}$ & 1 & $\begin{array}{c}0.04^{*} \\
(0.01)\end{array}$ & $\begin{array}{c}0.01 \\
(0.88)\end{array}$ & $\begin{array}{c}0.01 \\
(0.11)\end{array}$ & - & Category & $\mathrm{BC} \times \mathrm{BT} \times \mathrm{PS}$ \\
\hline $\mathrm{BT}$ & 2 & $\begin{array}{c}0.07 * \\
(0.01)\end{array}$ & $\begin{array}{c}0.11 \\
(0.01)\end{array}$ & $\begin{array}{c}0.06^{*} \\
(0.01)\end{array}$ & - & Category & $\mathrm{BC} \times \mathrm{BT} \times \mathrm{PS}$ \\
\hline PS & 1 & $\begin{array}{c}0.13^{*} \\
(<0.01)\end{array}$ & $\begin{array}{c}0.15^{*} \\
(<0.01)\end{array}$ & $\begin{array}{c}0.01 \\
(0.18)\end{array}$ & - & Category & $\mathrm{BC} \times \mathrm{BT} \times \mathrm{PS}$ \\
\hline $\mathrm{BC} \times \mathrm{BT}$ & 2 & $\begin{array}{c}0.01 * \\
(0.01)\end{array}$ & NS & NS & - & Interaction & $\mathrm{BC} \times \mathrm{BT} \times \mathrm{PS}$ \\
\hline $\mathrm{BT} \times \mathrm{PS}$ & 2 & NS & NS & $\begin{array}{c}0.03^{*} \\
(0.01)\end{array}$ & - & Interaction & $\mathrm{BC} \times \mathrm{BT} \times \mathrm{PS}$ \\
\hline $\mathrm{BC} \times \mathrm{BT} \times \mathrm{PS}$ & 7 & $\begin{array}{c}0.01 \\
(0.99)\end{array}$ & $\begin{array}{c}0.01 \\
(0.97)\end{array}$ & $\begin{array}{c}0.03 \\
(0.99)\end{array}$ & - & $\begin{array}{l}\text { Whole plot } \\
\text { error }\end{array}$ & Model error \\
\hline \multicolumn{8}{|l|}{ Subplot } \\
\hline $\mathrm{t}$ & 1 & $\begin{array}{c}0.03^{*} \\
(0.02)\end{array}$ & $\begin{array}{c}0.39 * \\
(<0.01)\end{array}$ & $\begin{array}{c}0.42^{*} \\
(<0.01)\end{array}$ & - & Continuous & Model error \\
\hline $\mathrm{t} \times \mathrm{PS}$ & 1 & $\mathrm{NS}$ & $\mathrm{NS}$ & $\begin{array}{c}0.08^{*} \\
(0.01)\end{array}$ & - & Interaction & Model error \\
\hline$(\mathrm{t} \times \mathrm{t}) \times \mathrm{PS}$ & 1 & NS & $\begin{array}{c}0.06^{*} \\
(0.01)\end{array}$ & $\mathrm{NS}$ & - & Interaction & Model error \\
\hline Error & 203 & 1.09 & - & - & - & & \\
\hline Error & 201 & - & 1.48 & - & - & & \\
\hline Error & 202 & - & - & 1.60 & - & & \\
\hline Error & & - & - & - & - & & \\
\hline $\mathrm{R}^{2}$ & & 0.21 & 0.32 & 0.28 & - & & \\
\hline
\end{tabular}

${ }^{1}$ Treatments: presalting the curd (presalted vs. not presalted), brine concentration (saturated brine vs. $18 \%$ brine), and brine temperature $\left(12,15\right.$, and $\left.18^{\circ} \mathrm{C}\right) . \mathrm{P} 1, \mathrm{P} 2, \mathrm{P} 3$, and $\mathrm{P} 4$ represent portions of the cheese block from exterior surface (P1) to interior core (P4).

${ }^{2}$ Factors: $\mathrm{BC}=$ brine concentration; $\mathrm{BT}=$ brine temperature; $\mathrm{PS}=$ presalting; $\mathrm{t}=$ time.

${ }^{3}$ Model not significant.

*Statistically significant $(P<0.05)$.

Table 12. Least squares mean values of the $\mathrm{pH}$ of cheese portions ${ }^{1}$ (P1, P2, P3, and P4) of Ragusano cheese, for the presalted and not presalted cheeses at 2 brine concentrations (18\% vs. saturated), and 3 brining temperatures $\left(12,15\right.$, and $\left.18^{\circ} \mathrm{C}\right)$ at $0,1,4,8,16$, and $24 \mathrm{~d}$ of brining

\begin{tabular}{lllll}
\hline Variable & P1 & P2 & P3 & P4 \\
\hline Presalting & $5.28^{\mathrm{a}}$ & $5.28^{\mathrm{a}}$ & $5.26^{\mathrm{a}}$ & $5.27^{\mathrm{a}}$ \\
No presalting & $5.23^{\mathrm{b}}$ & $5.23^{\mathrm{b}}$ & $5.24^{\mathrm{a}}$ & $5.26^{\mathrm{a}}$ \\
LSD & 0.02 & 0.02 & $\mathrm{NS}$ & $\mathrm{NS}$ \\
Saturated brine & $5.24^{\mathrm{b}}$ & $5.26^{\mathrm{a}}$ & $5.26^{\mathrm{a}}$ & $5.27^{\mathrm{a}}$ \\
$18 \%$ Brine & $5.27^{\mathrm{a}}$ & $5.26^{\mathrm{a}}$ & $5.25^{\mathrm{a}}$ & $5.27^{\mathrm{a}}$ \\
LSD & 0.02 & $\mathrm{NS}$ & $\mathrm{NS}$ & $\mathrm{NS}^{\mathrm{B}}$ \\
$12^{\circ} \mathrm{C}$ & $5.28^{\mathrm{a}}$ & $5.29^{\mathrm{a}}$ & $5.27^{\mathrm{a}}$ & $5.28^{\mathrm{a}}$ \\
$15^{\circ} \mathrm{C}$ & $5.26^{\mathrm{a}}$ & $5.26^{\mathrm{a}}$ & $5.25^{\mathrm{ab}}$ & $5.27^{\mathrm{a}}$ \\
$18^{\circ} \mathrm{C}$ & $5.24^{\mathrm{b}}$ & $5.23^{\mathrm{b}}$ & $5.23^{\mathrm{b}}$ & $5.26^{\mathrm{a}}$ \\
LSD & 0.02 & 0.03 & 0.03 & $\mathrm{NS}$ \\
\hline
\end{tabular}

${ }^{\mathrm{a}, \mathrm{b}}$ Means within salting method, brine concentration, and brine temperature not sharing the same superscript within a column are different $(P<0.05)$.

${ }^{1}$ Portions P1, P2, P3, and P4 represent portions of the cheese block from exterior surface (P1) to interior core (P4).

${ }^{2}$ Model not significant. loss during brining, while maximizing the combined effect of these salting conditions to minimize the risk of early gas production.

With respect to cheese yield, the impact of the combination of factors influencing salt uptake and salt content was quite dramatic. The common practice for manufacture of Ragusano cheese using a BT of $18^{\circ} \mathrm{C}$ in $\mathrm{SB}$ for $24 \mathrm{~d}$ with no PS produced a yield (i.e., weight) loss of $14.13 \%$ in $3.6-\mathrm{kg}$ blocks (calculated from data in Table 1) in $24 \mathrm{~d}$. This represents a very large loss. Use of the combination of PS and reduced BC allowed cheese makers to achieve the same salt in moisture concentration in less than $24 \mathrm{~d}$ (Figures 15 and 16). Reduced BT also reduces weight loss during brining (Table 3). The combination of PS, a BT of $15^{\circ} \mathrm{C}$, and $18 \% \mathrm{~B}$ for $8 \mathrm{~d}$ of brining would deliver adequate salt into all portions of cheese and reduce weight loss to $4.15 \%$ of the original block weight. This would be a net yield increase of $9.98 \%$, which is a very important economic opportunity for cheese makers. Ragusano cheese blocks in the present study were $3.6-\mathrm{kg}$ cubic blocks, whereas the typical commercial Ragusano cheese block is rectangular and weighs about $15 \mathrm{~kg}$ (Licitra et al., 2000). Size and shape 
of cheese blocks influences salt uptake, moisture loss, and the nature of salt and moisture gradients that develop within a block of cheese during brining (Guinee and Fox, 1986). As block size increases, the percentage of the total weight that is lost will be lower than the $14.13 \%$ for $3.6-\mathrm{kg}$ blocks in SB, but consideration of strategies to reduce cheese yield loss are still economically important in 15 -kg blocks.

\section{Combined Influence of PS, BC, and BT for Controlling Early Gas Formation}

Brine-salted cheeses have a lower moisture and harder exterior layer (rind). Typically, there is a gradation of cheese texture and flavor characteristics from the exterior to the interior center of the block with the highest quality cheese in the center (higher moisture and lower salt). This gradient of composition changes very little throughout the 6 to 9 mo of aging of the cheese (Licitra et al., 2000). Thus, the composition in the center region of the block is typical of the most desirable cheese and the conditions that favor proper flavor development. If moisture is too high, salt too low or too slow to penetrate the interior portions of the cheese, and $\mathrm{pH}$ too high, then there is a high probability of the development of early gas defects in Ragusano cheese and other brine-salted cheeses (Choisy et al., 1987; Kosikowski and Mistry, 1997). In traditional cheese making on farms the technologies are simple (Licitra et al., 1998). First, good milk quality combined with good cleaning and sanitation of cheese-making equipment will keep the load of undesirable gas producing organisms at low levels (Choisy et al., 1987). Next, a proper rate and amount of acid production by lactic acid bacteria to achieve a target milling $\mathrm{pH}$ of about 5.2 in a normal length of time allows the desirable lactic acid bacteria to predominate. Once the cheese is milled, then PS, controlling $\mathrm{BC}$, and $\mathrm{BT}$ are the next factors that could be used to advantage in a system to control undesirable gas formation in cheese. Although not done traditionally in the manufacture of Ragusano cheese and many other traditional pasta-filata cheeses, adding part of the salt to the curd before stretching in hot water is an approach that can ensure that a significant amount of salt is present in the interior portions of the blocks before early gas formation can begin. Although the presence of the salt in the interior of the cheese very early should be beneficial, an unexpected benefit of PS was discovered in this experiment and reported separately (Melilli et al., 2004b). The interaction of the salt in the curd and stretching water, combined with the temperature (about $48^{\circ} \mathrm{C}$ ) and $\mathrm{pH}$ (about 5.3) of the stretching step for Ragusano cheese was much more effective at killing undesirable gas-forming bacteria in the curd before brine salting than was expected and produced a $1.4 \mathrm{log}$ reduction in coliform count in the cheese before brine salting (Melilli et al., 2004b). This reduction in the initial load of undesirable bacteria coupled with a salt in moisture content throughout the cheese of about $2.5 \%$ at the beginning of brine salting significantly reduced gas formation compared with cheese that was not presalted. Although in the present study, the lower BT actually makes a minor reduction in salt penetration into cheese, the benefit of lower BT in retarding the growth and gas production by undesirable bacteria is more important than the reduction in salt uptake. Reducing salt concentration in brine from saturation to $18 \% \mathrm{NaCl}$ increased the rate of salt penetration into the block during brine salting, but was not effective at delivering salt rapidly into the interior of the block to control early gas formation. However, the use of $18 \% \mathrm{BC}$ does have a very beneficial impact on cheese yield by reducing moisture loss even if it has little effectiveness by itself in reducing early gas formation. While the $9.98 \%$ increase in cheese yield due to higher moisture content when using $18 \% \mathrm{BC}$ would be very attractive to a cheese maker, the use of $18 \% \mathrm{~B}$ may produce other risks to cheese quality and should be considered very carefully. Maintaining brine concentration at $18 \% \mathrm{NaCl}$ instead of SB is more difficult to control and may produce additional risks to cheese quality due to growth of undesirable bacteria in the more dilute brine and result in contamination of the cheese with bacteria that may produce off flavors.

First (and most importantly) farmstead cheese makers must maintain a high level of sanitation and keep the count of undesirable bacteria in the milk low. After improving raw milk quality, the most practical and safe course of action to minimize early gas formation is to add salt to curd ( $\mathrm{pH} 5.2$ ) to achieve about 30 to $50 \%$ of the final salt content in the cheese curd before stretching and to use slightly lower brine temperature (e.g., 15 instead of $18^{\circ} \mathrm{C}$ ) during brining. When using PS, the cheese will not have to remain in the brine as long as the traditional approach (Melilli et al., 2003a). This approach combined with good milk quality and proper acid development during the cheese-making process will reduce the probability of early gas development in the cheese. These conditions will produce a traditional cheese that still has a gradient of moisture content and typical appearance but with greatly reduced risk of early gas formation. Once the cheese has finished brining, then the temperature and time conditions of aging will determine the rate of subsequent proteolysis, lipolysis, and flavor development.

\section{CONCLUSIONS}

Although the BC, BT, and PS each had their own separate impacts on salt uptake, there was little inter- 
action of these effects on salt uptake when they were used in combination. The PS most quickly and effectively delivered salt to the interior of the cheese and was the most effective salting approach to control early gas formation. There were strong separate impacts of $\mathrm{BC}, \mathrm{BT}$, and PS on cheese moisture content, moisture loss, and net weight loss, with $\mathrm{BC}$ having the largest separate impact on these parameters. Reducing BT reduced salt content and increased moisture, but the effects were small. The more important impact of reduced BT was to reduce gas defects. The $18 \% \mathrm{~B}$ produced higher moisture, and less moisture and weight loss than $\mathrm{SB}$. The effect of interactions of BC, BT, and PS on moisture content, moisture loss, and net weight loss were small. To achieve the maximum benefit from the various approaches to salting for controlling early gas formation in Ragusano cheese, PS combined with slightly lower BT (i.e., $15^{\circ} \mathrm{C}$ instead of $18^{\circ} \mathrm{C}$ ) should be used. Although using 18\% B instead of SB did increase salt uptake, the point at which improved salt uptake occurred due to use of $18 \% \mathrm{~B}$ did not provide benefit in prevention of early gas formation, as reported separately. However, use of $18 \% \mathrm{~B}$ instead of SB provided a $9.98 \%$ increase in cheese yield due to reduced moisture loss during brining and this would be very attractive to cheese makers. The increase in yield needs to be balanced against the risk of growth of undesirable bacteria in the $18 \% \mathrm{~B}$ and the creation of another cheese quality defect.

\section{ACKNOWLEDGMENTS}

The authors thank Stefania La Terra, Giovanni Farina, Glenda Leto, Jessica Mallozzi, Mario Manenti, Lucia Cascone, Stefania Cilia, Giovanni Marino, Giovanni Tumino, Sebastiano Campo, Antonio Difalco, Giuseppe Schembari, Rosario Tumino, and Patrizia Campo for their technical assistance in cheese manufacture and cheese analysis. Financial support was provided by the Assessorato Agricoltura e Foreste della Regione Siciliana, Palermo, Italy.

\section{REFERENCES}

AOAC. 2000. Official Methods of Analysis. 17th ed. Association of Official Analytical Chemists International, Gaithersburg, MD.

Carić, M. 1993. Ripened cheese varieties native to Balkan countries. Pages 263-280 in Cheese Chemistry, Physics, and Microbiology, Vol. 2., Major Cheese Groups. P. F. Fox, ed. 2nd edition. Chapman and Hall, London, UK.

Choisy, C., M. Gueguen, J. Lenoir, J. L. Schmidt, and C. Tourneur. 1987. The ripening of cheese: Microbiological aspects. Pages 250
292 in Cheesemaking-science and technology. A. Eck, ed. Lavoisier Publ. Inc., New York, NY.

Fox, P. F., T. P. Guinee, T. M. Cogan, and P. L. H. McSweeney. 2000. Pages 153-168 in Fundamentals of Cheese Science. Apsen Publishers, Inc., Gaithersburg, MD.

Geurts, T. J., P. Walstra, and H. Mulder. 1972. Brine composition and the prevention of the defect "soft rind" in cheese. Neth. Milk Dairy J. 26:168-179.

Geurts, T. J., P. Walstra, and H. Mulder. 1974. Transport of salt and water during salting of cheese. 1 . Analysis of the processes involved. Neth. Milk Dairy J. 28:102-129.

Geurts, T. J., P. Walstra, and H. Mulder. 1980. Transport of salt and water during salting of cheese. 2. Quantities of salt taken up and moisture lost. Neth. Milk Dairy J. 34:229-254.

Glantz, S. A., and B. K. Slinker. 2001. Multicollinearity and what to do about it. Pages 185-187 in Primer of Applied Regression \& Analysis of Variance. 2nd edition. McGraw-Hill, Inc. New York, NY.

Guinee, T. P., and P. F. Fox. 1986. Influence of cheese geometry on the movement of sodium chloride and water during brining. Irish J. Food Sci. Technol. 10:73-96.

Guo, M. R., J. A. Gilmore, and P. S. Kindstedt. 1997. Effect of sodium chloride on the serum phase of Mozzarella cheese. J. Dairy Sci. 80:3092-3098.

Kosikowski, F. V., and V. V. Mistry. 1997. Page 228 in Cheese and Fermented Milk Foods. Vol. 1. Origins and Principles. F. V. Kosikowski, LLC, Westport, CT.

Licitra, G., P. Campo, M. Manenti, G. Portelli, S. Scuderi, S. Carpino, and D. M. Barbano. 2000. Composition of Ragusano cheese during aging. J. Dairy Sci. 83:404-411.

Licitra, G., G. Portelli, P. Campo, G. Longombardo, G. Farina, S. Carpino, and D. M. Barbano. 1998. Technology to produce Ragusano cheese: A survey. J. Dairy Sci. 81:3343-3349.

Melilli, C., D. M. Barbano, M. Caccamo, M. A. Calvo, G. Schembari, and G. Licitra. 2004b. Influence of brine concentration, brine temperature, and presalting on early gas defects in raw milk pasta filata cheese. J. Dairy Sci. 87:3648-3657.

Melilli, C., D. M. Barbano, G. Licitra, G. Portelli, G. Di Rosa, and S. Carpino. 2003b. Influence of temperature of salt brine on salt uptake by Ragusano cheese. J. Dairy Sci. 86:2799-2812.

Melilli, C., D. M. Barbano, G. Licitra, G. Tumino, G. Farina, and S. Carpino. 2003a. Influence of presalting and brine concentration on salt uptake by Ragusano cheese. J. Dairy Sci. 86:1083-1100.

Melilli, C., D. M. Barbano, M. Manenti, J. M. Lynch, S. Carpino, and G. Licitra. 2004a. Lipolysis and proteolysis in Ragusano cheese during brine salting at different temperatures. J. Dairy Sci. 87:2359-2374.

Melilli, C., D. Carcó, D. M. Barbano, G. Tumino, S. Carpino, and G. Licitra. 2005. Composition, microstructure, and surface barrier layer development during brine salting. J. Dairy Sci. 88:23292340.

Payne, M. R., and K. R. Morison. 1999. A multi-component approach to salt diffusion in cheese. Int. Dairy J. 9:887-894.

Resmini, P., G. Volonterio, S. Annibaldi, and G. Ferri. 1974. Studio sulla diffusione del sale nel formaggio Parmigiano-Reggiano mediante l'uso di $\mathrm{Na}^{36} \mathrm{Cl}$. Sci. Tecn. Latt. Cas. 25:149-166.

Turhan, M., and G. Kaletunç. 1992. Modelling of salting diffusion in White cheese during long term brining. J. Food Sci. 57:1082-1085.

Walstra, P., T. J. Geurts, A. Noomen, A. Jellema, and M. A. J. S. van Boekel. 1999. Pages 145-146 in Dairy Technology: Principles of Milk Properties and Processes. Marcel Dekker, Inc., New York, NY.

Zorrilla, S. E., and A. C. Rubiolo. 1991. Average $\mathrm{NaCl}$ concentration in cheese for different volume ratios of brine and solid during salting. J. Food Sci. 56:1548-1551. 